\title{
Analysis of antioxidant capacity and bioactive compounds in marine macroalgal and lichenic extracts using different solvents and evaluation methods
}

\section{Análisis de la capacidad antioxidante y compuestos bioactivos en extractos macroalgales y liquénicos mediante la aplicación de diferentes solventes y métodos de evaluación}

\author{
Félix Álvarez-Gómez*, Nathalie Korbee, Félix L Figueroa \\ Department of Ecology and Geology, Faculty of Sciences, International Campus of Excellence Andalucia Tech, \\ University of Málaga, 29071 Málaga, Spain. \\ * Corresponding author. E-mail: felix_alvarez000@hotmail.com
}

\begin{abstract}
Natural extracts of macroalgae are widely recognized for their antioxidant properties. In this work, the antioxidant capacity of various aqueous and hydroalcoholic extracts obtained from red and green marine algae and from one marine lichen collected from different sites in southern Spain (intertidal and estuarine waters) was evaluated by different methods: ABTS free radical scavenging assay, DPPH assay, and $\beta$-carotene bleaching method (BBM). Contents of total lipids, total carbohydrates, and UV photoprotectors with antioxidant capacity, such as mycosporine-like amino acids and phenolic compounds, were determined. Among the extraction solvents, the highest extraction yield was observed in $\mathrm{H}_{2} \mathrm{O}$ and $20 \% \mathrm{MeOH}(\mathrm{v} / \mathrm{v})$. The highest antioxidant activity was found in the extracts of the red macroalgae Hydropuntia cornea, Gracilariopsis longissima, Halopithys incurva, and Porphyra umbilicalis, whereas the lowest activity was detected in the green macroalga Ulva rotundata. In general, the antioxidant activity was higher using DPPH than BBM and ABTS. Even so, the ABTS assay is an easy and quick test that provides a comprehensive view of the entire extract in both the lipophilic medium and hydrophilic medium. The antioxidant activity was related to the composition of bioactive compounds and synergistic action is not discarded. The biotechnological use of macroalgal extracts with high antioxidant capacity is discussed.
\end{abstract}

Key words: antioxidants, bioactive compounds, extracts, lichen, macroalgae.

RESUMEN. Los extractos naturales de las macroalgas son ampliamente reconocidos por sus propiedades antioxidantes. En este trabajo la capacidad antioxidante de diversos extractos acuosos e hidroalcohólicos obtenidos de algas marinas (rojas y verdes) y de un liquen marino, recolectados en diferentes puntos del sur de España (aguas intermareales y estuarinas), fue evaluada mediante diferentes métodos: método ABTS, ensayo DPPH y método de decoloración del $\beta$-caroteno (BBM). Se determinó el contenido de lípidos totales, carbohidratos totales y fotoprotectores de radiación UV con capacidad antioxidante como los aminoácidos de tipo micosporina y compuestos fenólicos. Entre los solventes de extracción, el mayor rendimiento de extracción se observó en los solventes $\mathrm{H}_{2} \mathrm{O}$ y $\mathrm{MeOH} 20 \%$ ( $/ \mathrm{v}$ ). La mayor actividad antioxidante se encontró en los extractos de las macroalgas rojas Hydropuntia cornea, Gracilariopsis longissima, Halopithys incurva y Porphyra umbilicalis, mientras que la actividad más baja se detectó en los de la macroalga verde Ulva rotundata. En general, la actividad antioxidante fue mayor usando el ensayo DPPH que el método ABTS y el BBM. Aun así, se propone el método ABTS como una prueba sencilla y rápida que proporciona una visión completa del extracto en su conjunto, ya que mediante esta metodología se evalúan los componentes que se encuentran tanto en el medio lipofílico como el medio hidrofílico. La actividad antioxidante se relacionó con la composición de compuestos bioactivos sin descartar la acción sinérgica entre sus compuestos. Se discute el uso biotecnológico de los extractos de macroalgas con alta capacidad antioxidante.

Palabras clave: antioxidantes, compuestos bioactivos, extractos, líquenes, macroalgas.

\section{INTRODUCTION}

Marine organisms, including algae and lichen, have attracted the attention of many researchers as sources of bioactive compounds because of their properties, the diversity of their molecules, and their novel chemical structures which are complex and difficult to synthesize chemically. Seaweeds provide an excellent source of bioactive compounds such as carotenoids, polysaccharides, proteins, lipids, fatty acids, pigments, vitamins, polyphenols, and microelements, among others (Borowitzka 2013). Biochemical compounds from

\section{INTRODUCCIÓN}

Los organismos marinos, incluyendo las algas y los líquenes, han atraído la atención de muchos investigadores como fuente de compuestos bioactivos debido a sus propiedades, la diversidad de sus moléculas y sus nuevas estructuras químicas que son complejas y difíciles de sintetizar químicamente. Las algas proporcionan una excelente fuente de compuestos bioactivos como carotenoides, polisacáridos, proteínas, lípidos, ácidos grasos, pigmentos, vitaminas, polifenoles y microelementos, entre otras sustancias (Borowitzka 
algae are currently used as ingredients with bioactive properties in cosmeceutical products. These cosmetic products differ from classic cosmetics in that they have therapeutic or pharmacological properties. Lichens are also well known due to the diversity of the secondary metabolites that they produce known as lichenic substances. Recently, there is increased interest in natural active compounds as an alternative to synthetic substances. Although these compounds often show lower activity, they are nontoxic and do not generate residues.

Antioxidants present in extracts from algae and lichen are of special interest for use in cosmetics and nutraceuticals (oral and topical formulations) since their potential toxicity and health risks are not as great as that of synthetic antioxidants (Thomas and Kim 2013). Pharmacological activities (antitumor and anti-inflammatory) have been closely related to oxidative imbalance. Antioxidant properties of algal natural compounds can increase the shelf life of foods and cosmetics through delayed oxidation (Chintali Ashwini et al. 2013). In addition to antioxidants, algae also provide other ingredients used in the formulation of cosmetic products, such as other bioactive ingredients, minerals, polysaccharides, etc. This supports the use of algae and lichen to advance human health, as functional foods and/or dietary supplements, due to the positive impact that their use would have in the prevention and/or treatment of pathologies linked to oxidative stress (Yuan and Walsh 2006).

This study aims to evaluate the antioxidant activity of algal extracts and one marine lichen extract by using different solvents, related to different mechanisms of action, which can be explained by the presence of various metabolites (Batista-González et al. 2009). We quantified the content of algal and lichenic compounds with potential bioactive properties, such as carbohydrates, lipids, and UV-screen substances with antioxidant capacity like polyphenols and mycosporine-like amino acids (MAAs) (Stengel et al. 2011). These compounds show important applications in a range of products in the food, pharmaceutical, and cosmetic industries.

The following species were selected for this study because they can be intensively cultured in integrated multitrophic aquaculture systems (Gómez-Pinchetti et al. 2011) and because of the potential biotechnological use of the algal biomass: Gelidium corneum (Hudson) JV Lamouroux and Gelidium pusillum (Stackhouse) Le Jolis (Rabiei et al. 2016); Porphyra umbilicalis Kützing (Pereira and Yarish 2010); Halopithys incurva (Hudson) Batters (Güenaga 2011); Gracilariopsis longissima (SG Gmelin) M Steentoft, LM Irvine, and WF Farnham (Hernández et al. 2006); Hydropuntia cornea (J Agardh) MJ Wynne (Figueroa et al. 2012); and Ulva rotundata Bliding (Martínez-Aragón et al. 2002). The culture of Lichina pygmaea (OF Müller) C Agardh is currently not feasible, so it is only possible to cultivate photobionts of the cyanobacterial genus Calothrix for the production of metabolites of interest. The symbiosis
2013). Los compuestos bioquímicos de algas se usan actualmente como ingredientes con propiedades bioactivas en productos cosmecéuticos. Estos productos cosméticos se diferencian de los productos cosméticos clásicos porque presentan propiedades terapeúticas o farmacológicas. Los líquenes también son bien conocidos debido a la diversidad de sus metabolitos secundarios denominados sustancias liquénicas. Recientemente, existe un gran interés en los compuestos activos naturales como alternativa a las sustancias sintéticas. Aunque estos compuestos, a menudo, muestran una menor actividad, no son tóxicos ni generan residuos.

Los antioxidantes presentes en extractos de algas y líquenes son de interés especial para su uso en cosméticos y productos nutracéuticos (mediante vía oral o tópica) ya que sus posibles riesgos de toxicidad y salud no son tan grandes como la de antioxidantes sintéticos (Thomas y Kim 2013). Las actividades farmacológicas (antitumorales y antiinflamatorias) han estado estrechamente relacionadas con el desequilibrio oxidativo. Las propiedades antioxidantes de los compuestos naturales de algas pueden aumentar la vida útil de los alimentos y cosméticos a través de la oxidación (Chintali Ashwini et al. 2013). Además de los antioxidantes, las algas también proporcionan otros ingredientes utilizados en la formulación de productos cosméticos, tales como otros ingredientes bioactivos, minerales, polisacáridos, etc. Esto apoya la utilización de algas y líquenes como suplementos farmacéuticos funcionales y/o dietéticos para mejorar la salud humana debido al impacto positivo que su uso tendría en la prevención y/o el tratamiento de patologías relacionadas con el estrés oxidativo (Yuan y Walsh 2006).

El objetivo de este estudio es evaluar la actividad antioxidante de los extractos de algas marinas y de un liquen marino mediante la utilización de distintos solventes, relacionados con los diferentes mecanismos de acción, la cual se explicaría por la presencia de diversos metabolitos extraídos con dichos solventes (Batista-González et al. 2009). Se cuantificó el contenido de compuestos algales y liquénicos con propiedades bioactivas potenciales, tales como carbohidratos, lípidos y sustancias fotoprotectoras UV con capacidad antioxidante como polifenoles y aminoácidos de tipo micosporina (AAM) (Stengel et al. 2011). Estos compuestos muestran aplicaciones importantes en una gama de productos en la industria alimentaria, farmacéutica y cosmética.

Las siguientes especies fueron seleccionadas para este estudio con base en su capacidad de ser cultivadas, de manera intensiva, en sistemas de acuicultura multitrófica integrada (Gómez-Pinchetti et al. 2011) y el uso biotecnológico potencial de su biomasa: Gelidium corneum (Hudson) JV Lamouroux y Gelidium pusillum (Stackhouse) Le Jolis (Rabiei et al. 2016); Porphyra umbilicalis Kützing (Pereira y Yarish 2010); Halopithys incurva (Hudson) Batters (Güenaga 2011); Gracilariopsis longissima (SG Gmelin) M Steentoft, LM Irvine y WF Farnham (Hernández et al. 2006); Hydropuntia cornea (J Agardh) MJ Wynne (Figueroa et al. 2012); y Ulva rotundata Bliding (Martínez-Aragón et al. 
between photobiont and mycobiont is probably more favorable for the production of bioactive compounds due to the synergies that may arise between both organisms.

\section{MATERIALS AND METHODS}

Seven clean and fresh macroalgae and one marine lichen were collected in coastal areas of different geographic locations at the same or approximately the same moment in time. The biomass was placed in a portable ice chest (approximately $-4{ }^{\circ} \mathrm{C}$ ) for 3-4 h. All species were collected at Tarifa, Cádiz, Spain $\left(36^{\circ} 00^{\prime} 10^{\prime \prime} \mathrm{N}, 5^{\circ} 36^{\prime} 33^{\prime \prime} \mathrm{W}\right)$, except Gracilariopsis longissima (San Pedro River, Cádiz, Spain; $36^{\circ} 32^{\prime} 52^{\prime \prime} \mathrm{N}, 6^{\circ} 12^{\prime} 33^{\prime \prime} \mathrm{W}$ ), Hydropuntia cornea (Gran Canaria, Canary Islands, Spain, $27^{\circ} 59^{\prime} 28^{\prime \prime} \mathrm{N}, 15^{\circ} 22^{\prime} 8^{\prime \prime} \mathrm{W}$ ), and $U$. rotundata (Málaga, Málaga, Spain; $36^{\circ} 42^{\prime} 41^{\prime \prime} \mathrm{N}$, $\left.4^{\circ} 19^{\prime} 33^{\prime \prime} \mathrm{W}\right)$. Only $H$. cornea was obtained from cultures (algal densities 6-8 $\mathrm{g}$ fresh weight per liter) in tanks located in a greenhouse.

Algae were dried between sheets of paper to remove excess moisture and frozen at $-20^{\circ} \mathrm{C}$ until the analysis. Extraction was done with various alcoholic and hydroalcoholic solvents: distilled $\mathrm{H}_{2} \mathrm{O}(100 \%)$, EtOH (100\%), EtOH $(50 \%)$, and $\mathrm{MeOH}(20 \%)$. For each extract, $10 \mathrm{~g}$ fresh weight of algal thallus was used. Thalli were ground in a mortar (placed on a bed of ice) with $150 \mathrm{~mL}$ of the above-cited solvents. Sterile beach sand was used to achieve greater abrasion. The extracts were incubated in a thermal bath (SS40-2, Grant Instruments, Cambridge, UK) at $45 \pm 2{ }^{\circ} \mathrm{C}$ with constant stirring for $6 \mathrm{~h}$. After this time, the first extracts were filtered through a $100-\mu \mathrm{m}$ mesh and then centrifuged (Beckman GS-15 R centrifuge) for $10 \mathrm{~min}$ at $4{ }^{\circ} \mathrm{C}$. Finally, the supernatant was concentrated on a Buchi R-210 rotary evaporator.

The extraction yields $(\eta)$ for each solvent were calculated after extraction. The yields related to the extracted biomass (dry weight) were calculated according to the following formula: $(\eta \%)=\left(\operatorname{solubilized}_{(\text {obtained })} /\right.$ biomass $\left._{(\text {provided })}\right) \times 100$. Solubilized $_{\text {(obtained) }}$ (in grams dry weight) is the amount of material extracted from the biomass with the different solvents and biomass (provided) $_{\text {is }}$ is the amount of biomass (in grams) used to make the extraction. The fresh weight:dry weight ratio $(\mathrm{FW} / \mathrm{DW})$ was calculated for each species-after keeping the samples for $24 \mathrm{~h}$ at $60^{\circ} \mathrm{C}$.

The organic matter content (\%) was estimated by measuring the loss on ignition at $550{ }^{\circ} \mathrm{C}$ during $3.5 \mathrm{~h}$. Biochemical tests were performed in triplicate.

\section{Methods for testing antioxidant activity}

The DPPH assay was performed according to the method developed by Kim et al. (2002). The reaction was complete after $30 \mathrm{~min}$ in the dark at room temperature $\left(\sim 20^{\circ} \mathrm{C}\right)$ because light can degrade the generated radical. The absorbance was read at $517 \mathrm{~nm}$ in a spectrophotometer (UVMini-1240 model, Shimadzu, Columbia, USA).
2002). Cabe destacar que el cultivo de Lichina pygmaea (OF Müller) C Agardh es actualmente inviable, por lo que sólo es posible cultivar los fotobiontes del género Calothrix (cianobacterias) para la producción de metabolitos de interés. Es probable que la simbiosis entre el fotobionte y el micobionte sea más favorable para la producción de compuestos bioactivos debido a las sinergias que pueden surgir entre ambos organismos.

\section{MATERIALES Y MÉTODOS}

Siete macroalgas limpias y frescas y un liquen marino fueron recolectados en áreas costeras de diferentes lugares geográficos al mismo tiempo y en los mismos periodos temporales. La biomasa se colocó en un refrigerador de hielo portátil (aproximadamente $-4{ }^{\circ} \mathrm{C}$ ) durante $3-4 \mathrm{~h}$. Todas las especies fueron recolectadas en Tarifa, Cádiz, España $\left(36^{\circ} 00^{\prime} 10^{\prime \prime} \mathrm{N}, 5^{\circ} 36^{\prime} 33^{\prime \prime} \mathrm{W}\right)$, excepto Gracilariopsis longissima

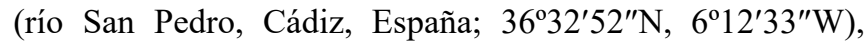
Hydropuntia cornea (Gran Canaria, islas Canarias; $\left.27^{\circ} 59^{\prime} 28^{\prime \prime} \mathrm{N}, 15^{\circ} 22^{\prime} 8^{\prime \prime} \mathrm{W}\right)$ y $U$. rotundata (Málaga, Málaga, España; $\left.36^{\circ} 42^{\prime} 41^{\prime \prime} \mathrm{N}, 4^{\circ} 19^{\prime} 33^{\prime \prime} \mathrm{W}\right)$. Sólo $H$. cornea fue obtenida a partir de cultivos (densidades de alga de $6-8 \mathrm{~g}$ de peso fresco por litro) en tanques situados en un invernadero.

Las algas se secaron entre hojas de papel para eliminar el exceso de humedad y se congelaron a $-20{ }^{\circ} \mathrm{C}$ hasta el momento de su análisis. La extracción se realizó con diversos solventes alcohólicos e hidroalcohólicos: $\mathrm{H}_{2} \mathrm{O}$ destilada (100\%), EtOH (100\%), EtOH (50\%) y $\mathrm{MeOH}(20 \%)$. Para cada extracto, se utilizaron $10 \mathrm{~g}$ de peso fresco de los talos de algas. Los talos se colocaron en un mortero con $150 \mathrm{~mL}$ de los solventes citados anteriormente, y se utilizó arena estéril para facilitar la extracción por abrasión. El mortero se colocó sobre un soporte de hielo. Posteriormente, los extractos se incubaron en un baño térmostatizado (modelo SS40-2, Grants Instruments, Cambridge, RU) a $45 \pm 2{ }^{\circ} \mathrm{C}$ con agitación constante durante $6 \mathrm{~h}$. Después de este tiempo, los primeros extractos se filtraron a través de una malla de $100 \mu \mathrm{m}$ y luego se centrifugaron (centrífuga Beckman GS-15R) durante $10 \mathrm{~min}$ a $4{ }^{\circ} \mathrm{C}$. Finalmente, el sobrenadante se concentró en un rotavapor Buchi R-210.

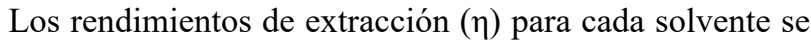
calcularon después de realizar la extracción. Se calcularon los rendimientos de extracción relacionados con la biomasa extraída (en peso seco) de acuerdo con la siguiente fórmula: $(\eta \%)=\left(\right.$ solubilizado $\left._{\text {(obtenido) }}\right) /$ biomasa $\left._{(\text {proporcionada })}\right) \times 100 . \mathrm{El}$ solubilizado $_{\text {(obtenido) }}$ (en gramos de peso seco) es la cantidad de material extraído de la biomasa con los diferentes solventes y

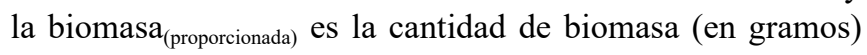
utilizada para realizar la extracción. La relación peso fresco/ peso seco (PF/PS) se calculó para cada especie tras mantener las muestras durante $24 \mathrm{~h}$ a $60^{\circ} \mathrm{C}$.

El contenido de materia orgánica (\%) se estimó midiendo la pérdida de material por ignición a $550{ }^{\circ} \mathrm{C}$ durante $3.5 \mathrm{~h}$. Todos los ensayos bioquímicos fueron realizados por triplicado. 
The ABTS assay was performed as described by Re et al. (1999). The mixture was allowed to stand for $8 \mathrm{~min}$ at room temperature and the absorbance was immediately recorded at $413 \mathrm{~nm}$. The antioxidant activity of the extracts measured by the DPPH and ABTS assays was calculated by following the same mathematical procedure.

The $\beta$-carotene bleaching method (BBM) was performed according to Hidalgo et al. (1994). The decrease in absorbance at $470 \mathrm{~nm}$ for 90 min was monitored when the extract was added to the solution. The antioxidant activity (AA\%) was calculated according to the following equation: $\left[\mathrm{AA}^{2}=\left(\right.\right.$ slope $_{\text {(sample) }}-\operatorname{slope}_{\text {(control) }} /$ slope $\left.\left._{(\text {control) }}\right) \times 100\right]$. Slope refers to the slopes of the obtained discoloration curve (absorbance/time). For this, the part of the curve describing linear behavior was adjusted by linear regression. A Trolox solution $(0-15 \mu \mathrm{M})$ was used as a standard for the 3 different methods tested. The results were expressed as micromoles of Trolox equivalents per gram of dry weight $\left(\mu \mathrm{mol} \mathrm{TE} \mathrm{g}^{-1} \mathrm{DW}\right)$. The values shown in this study are for each species and for each method used.

Total internal carbon and nitrogen contents were determined in an elemental analyzer (LECO-932 CNHS, Michigan, USA) and C:N ratios were calculated.

Quantification of total carbohydrates was conducted by the anthrone method (Brooks et al. 1986). Results were expressed as starch equivalent (\% starch) by multiplying by a factor of 0.9 .

Total lipid contents in the extracts were quantified by the sulfo-phospho-vanillin (SPV) method according to Mishra et al. (2014). To obtain the standard curve, triolein was used as standard at the final concentrations of $0.1-0.6 \mathrm{mg} \mathrm{L}^{-1}$.

Phenolic compounds were determined after the incubation period according to Folin and Ciocalteau (1927). Phloroglucinol was used for the standard calibration curve.

The MAAs were analyzed with a Waters HPLC system (Waters 600) as described by Korbee-Peinado et al. (2004), using published extinction coefficients.

\section{Statistical analysis}

Analysis of variance (ANOVA) was used to test the differences in the studied variables. Two-way ANOVA was used to detect significant differences among different antioxidant assays and solvents among species, and one-way ANOVA was used for the other variables. Homogeneity of variance was tested using the Cochran test and by visual inspection of the residuals for both analysis. Student-Newman-Keuls (SNK) tests were performed after significant ANOVA (post hoc analysis). Correlations among data obtained were calculated using Pearson's correlation coefficient $(r)$. All analyses were done with SPSS v10.0 for Windows (SPSS, Chicago, IL, USA).

\section{Métodos para evaluar la actividad antioxidante}

El ensayo DPPH se realizó de acuerdo con el método desarrollado por Kim et al. (2002). La reacción se completó después de $30 \mathrm{~min}$ en oscuridad a temperatura ambiente $\left(\sim 20^{\circ} \mathrm{C}\right)$ debido a que la luz puede degradar el radical generado. La absorbancia se leyó a $517 \mathrm{~nm}$ en un espectrofotómetro (modelo UVMini-1240, Shimadzu, Columbia, EUA).

El método ABTS se realizó de acuerdo con Re et al. (1999). La reacción finalizó tras $8 \mathrm{~min}$ a temperatura ambiente y se registró inmediatamente la absorbancia a $413 \mathrm{~nm}$. La actividad antioxidante de los extractos evaluados mediante DPPH y ABTS se calculó siguiendo el mismo procedimiento matemático.

El método de decoloración del $\beta$-caroteno (BBM) se realizó de acuerdo con Hidalgo et al. (1994). Se monitorizó la disminución de la absorbancia a $470 \mathrm{~nm}$ durante $90 \mathrm{~min}$ tras la adición del extracto a la solución. La actividad antioxidante (AA\%) se calculó de acuerdo con la siguiente ecuación usando las pendientes: $\left[\mathrm{AA} \%=\right.$ pendiente $_{(\text {muestra })}-$ pendiente $_{(\text {control) }} /$ pendiente $\left.\left._{(\text {control })}\right) \times 100\right]$. Las pendientes se calcularon a partir de la curva de decoloración obtenida (absorbancia/tiempo). Para ello, se utilizó la parte de la curva que describe un comportamiento lineal mediante ajustes de regresión lineal. Se usó el antioxidante de referencia Trolox $(0-15 \mu \mathrm{M})$ como solución estándar para los 3 métodos. Los resultados se expresaron como micromoles de equivalentes Trolox por gramo de peso seco ( $\mu \mathrm{mol} \mathrm{TE} \mathrm{g}^{-1} \mathrm{PS}$ ). Los valores mostrados en este estudio son para cada especie y para cada método utilizado.

El contenido total de carbono y nitrógeno interno se determinó en un analizador elemental LECO-932 CNHS (Michigan, EUA) y se calcularon las relaciones C:N.

La cuantificación de los carbohidratos totales se llevó a cabo mediante el método de la antrona (Brooks et al. 1986). Los resultados se expresaron como almidón equivalente (\% almidón) multiplicando por el factor 0.9 .

Los contenidos totales de lípidos en los extractos se cuantificaron mediante el método de la sulfo-fosfo-vainillina (SPV) según Mishra et al. (2014). Para obtener la curva estándar, se usó trioleína a concentraciones finales de $0.1-0.6 \mathrm{mg} \mathrm{L}^{-1}$.

Los compuestos fenólicos se determinaron después del periodo de incubación siguiendo el procedimiento descrito por Folin y Ciocalteau (1927). Se usó floroglucinol para la preparación de la curva patrón.

Los AAM se analizaron mediante HPLC (Waters 600), tal como se describió en Korbee-Peinado et al. (2004), utilizando los coeficientes de extinción ya publicados.

\section{Análisis estadístico}

Se utilizaron análisis de varianza (ANDEVA) para determinar las diferencias en las variables estudiadas. Se 


\section{RESULTS}

The FW/DW ratio was 4.75 for Gelidium pusillum, 3.05 for Gelidium corneum, 5.60 for Porphyra umbilicalis, 3.68 for Halopithys incurva, 7.57 for Gracilariopsis longissima, 9.17 for Hydropuntia cornea, 2.54 for Ulva rotundata, and 3.67 for Lichina pygmaea. The water content in the studied species varied between $60 \%$ and $90 \%$ (Table 1) and the organic matter content ranged from $9.4 \%$ in Halopithys incurva to the lowest values of less than $6 \%$ in Gracilariopsis longissima and Hydropuntia cornea (Table 1). Ash content was very high in $U$. rotundata and L. pygmaea (about $32 \%$ ), whereas the minimal value of $5.3 \%$ was found in $H$. cornea (Table 1).

The yield extraction was significantly different $(P<0.01)$ depending on the solvent used (Fig. 1). The order of the yield extraction, from high to low, was as follows: $20 \% \mathrm{MeOH}=$ $\mathrm{H}_{2} \mathrm{O} ; \mathrm{H}_{2} \mathrm{O}=50 \%$ EtOH; $50 \% \mathrm{EtOH}=100 \%$ EtOH (Fig. 1).

The antioxidant capacities of the 8 species were tested with 3 antioxidant methods. In the case of the DPPH and ABTS methods, the solvent that showed the highest value in the assays was $50 \% \mathrm{EtOH}$ (for $66.7 \%$ and $44.4 \%$ of the species studied, respectively). However, in the case of BBM, the solvent with the best result was $100 \% \mathrm{EtOH}$ (for $44.7 \%$ of the species). For all the macroalgal species, significant interactions were found between the factors "solvent" and "method" $(P<0.01)$. In the case of Gelidium pusillum, the highest activity in the DPPH assay $\left(9.65 \mu \mathrm{mol} \mathrm{TE} \mathrm{g}^{-1} \mathrm{DW}\right)$ $(P<0.01)$ was found in $50 \%$ EtOH (Fig. 2a). The highest antioxidant capacity was observed in both ethanolic solvents (50\% EtOH and $100 \% \mathrm{EtOH})$. This same pattern was found for Gelidium corneum, although there was no significant difference between the $50 \% \mathrm{EtOH}$ and $100 \% \mathrm{EtOH}$ solvents in the DPPH assay, which showed greater activity (Fig. 2b). In the case of $P$. umbilicalis (Fig. 2c), the aqueous solvent realizaron ANDEVA de 2 vías para detectar diferencias significativas entre los diferentes ensayos antioxidantes y los solventes empleados para cada especie, y ANDEVA de una vía para las demás variables estudiadas. La homogeneidad de la varianza se calculó usando la prueba de Cochran mediante inspección visual de los residuos para ambos análisis. Las pruebas de Student-Newman-Keuls (SNK) se realizaron después de encontrar diferencias significativas en los ANDEVA (análisis post hoc). Las correlaciones entre los datos obtenidos se calcularon utilizando el coeficiente de correlación de Pearson (r). Todos los análisis se realizaron con el software SPSS v10.0 para Windows (SPSS, Chicago, IL, EUA).

\section{RESUltados}

La relación PF/PS fue de 4.75 para Gelidium pusillum, 3.05 para Gelidium corneum, 5.60 para Porphyra umbilicalis, 3.68 para Halopithys incurva, 7.57 para Gracilariopsis longissima, 9.17 para Hydropuntia cornea, 2.54 para Ulva rotundata y 3.67 para Lichina pygmaea. El contenido de agua de las especies estudiadas varió entre $60 \%$ y $90 \%$ (Tabla 1 ) y el porcentaje de materia orgánica varió de $9.4 \%$ en Halopithys incurva a $6 \%$ en Gracilariopsis longissima y Hydropuntia cornea. El porcentaje de cenizas fue muy alto en $U$. rotundata y $L$. pygmaea (aproximadamente $32 \%$ ), mientras que el valor mínimo fue de $5.3 \%$ en $H$. cornea (Tabla 1).

El rendimiento de extracción fue significativamente diferente $(P<0.01)$ dependiendo del solvente utilizado (Fig. 1). $\mathrm{El}$ orden de los rendimientos de extracción fue, de mayor a menor, el siguiente: $\mathrm{MeOH} 20 \%=\mathrm{H}_{2} \mathrm{O} ; \mathrm{H}_{2} \mathrm{O}=\mathrm{EtOH} 50 \%$; EtOH $50 \%=$ EtOH $100 \%$ (Fig. 1).

Las capacidades antioxidantes de las 8 especies se probaron con 3 métodos antioxidantes. En el caso de los métodos

Table 1. Carbon and nitrogen content, humidity, organic matter, and ash in the different species analyzed. Each value is presented as mean \pm standard error $(n=3)$ : C, N, and C:N ratio based on percent dry weight $(\mathrm{v} / \mathrm{v})$; humidity, organic matter, and ash based on percent fresh weight. Different letters in the same column indicate significant differences among species $(P<0.05)$.

Tabla 1. Contenido de carbono y nitrógeno, humedad, materia orgánica y cenizas para las diferentes especies. Cada valor se representa como media \pm error estándar $(n=3)$ : C, N y C:N expresados en porcentaje del peso seco $(\mathrm{v} / \mathrm{v})$; humedad, materia orgánica y cenizas expresadas en porcentaje del peso fresco. Las letras diferentes en una misma columna indican diferencias significativas entre las especies $(P<0.05)$.

\begin{tabular}{lcccccc}
\hline Species & $\mathrm{C}(\%)$ & $\mathrm{N}(\%)$ & $\mathrm{C}: \mathrm{N}$ & Humidity $(\%)$ & Organic matter $(\%)$ & Ash $(\%)$ \\
\hline Gelidium pusillum & $36.1 \pm 0.0^{\mathrm{b}}$ & $3.8 \pm 0.0^{\mathrm{g}}$ & $9.4 \pm 0.1^{\mathrm{b}}$ & $79.1 \pm 1.3^{\mathrm{c}}$ & $6.7 \pm 0.9^{\mathrm{a}}$ & $13.3 \pm 1.3^{\mathrm{bc}}$ \\
Gelidium corneum & $35.8 \pm 0.1^{\mathrm{b}}$ & $3.6 \pm 0.0^{\mathrm{f}}$ & $10.0 \pm 0.1^{\mathrm{b}}$ & $71.7 \pm 0.3^{\mathrm{b}}$ & $6.6 \pm 1.4^{\mathrm{a}}$ & $24.9 \pm 0.2^{\mathrm{d}}$ \\
Porphyra umbilicalis & $30.2 \pm 0.4^{\mathrm{e}}$ & $2.9 \pm 0.1^{\mathrm{e}}$ & $10.5 \pm 0.4^{\mathrm{b}}$ & $82.1 \pm 0.7^{\mathrm{d}}$ & $8.4 \pm 0.5^{\mathrm{a}}$ & $12.4 \pm 0.4^{\mathrm{b}}$ \\
Halopythis incurva & $29.3 \pm 0.5^{\mathrm{d}}$ & $1.7 \pm 0.1^{\mathrm{c}}$ & $17.1 \pm 0.4^{\mathrm{c}}$ & $70.6 \pm 0.2^{\mathrm{b}}$ & $9.4 \pm 1.3^{\mathrm{a}}$ & $16.9 \pm 2.2^{\mathrm{c}}$ \\
Gracilariopsis longissima & $30.2 \pm 0.3^{\mathrm{e}}$ & $1.6 \pm 0.0^{\mathrm{b}}$ & $19.5 \pm 0.7^{\mathrm{d}}$ & $85.4 \pm 1.1^{\mathrm{e}}$ & $5.5 \pm 0.7^{\mathrm{a}}$ & $8.5 \pm 0.7^{\mathrm{a}}$ \\
Hydropuntia cornea & $26.6 \pm 0.2^{\mathrm{c}}$ & $1.5 \pm 0.1^{\mathrm{b}}$ & $18.2 \pm 0.7^{\mathrm{c}}$ & $88.9 \pm 0.5^{\mathrm{f}}$ & $5.7 \pm 0.5^{\mathrm{a}}$ & $5.3 \pm 0.9^{\mathrm{a}}$ \\
Ulva rotundata & $22.2 \pm 0.1^{\mathrm{a}}$ & $2.4 \pm 0.0^{\mathrm{d}}$ & $9.5 \pm 0.0^{\mathrm{b}}$ & $60.6 \pm 0.3^{\mathrm{a}}$ & $5.8 \pm 0.9^{\mathrm{a}}$ & $31.9 \pm 1.5^{\mathrm{e}}$ \\
Lichina pygmaea & $38.9 \pm 0.1^{\mathrm{g}}$ & $6.2 \pm 0.1^{\mathrm{h}}$ & $6.3 \pm 0.0^{\mathrm{a}}$ & $59.4 \pm 0.9^{\mathrm{a}}$ & $7.4 \pm 0.3^{\mathrm{a}}$ & $32.2 \pm 0.9^{\mathrm{e}}$ \\
\hline
\end{tabular}




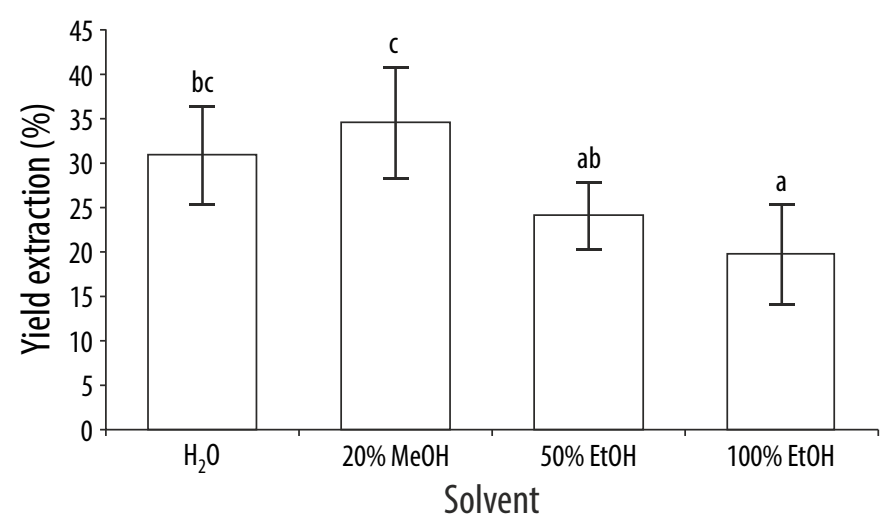

Figure 1. Extraction yields (\% yield $[\mathrm{v} / \mathrm{v}])$ for the solvents used. Data are expressed as the mean of all analyzed species (mean \pm standard error; $n=27)$. Different letters indicate significant differences among solvents $(P<0.05)$.

Figura 1. Rendimiento de extracción ( $\%$ rendimiento $[\mathrm{v} / \mathrm{v}])$ para los solventes. Los datos se expresan como la media de todas las especies analizadas (media \pm error estándar; $n=27$ ). Las letras diferentes indican diferencias significativas entre los solventes $(P<0.05)$.

showed similar results for DPPH and ABTS. Antioxidant activity for DPPH and BBM was also the same for the $\mathrm{H}_{2} \mathrm{O}, 100 \% \mathrm{EtOH}$, and $20 \% \mathrm{MeOH}$ extracts $(P>0.05)$. The solvent that showed the highest extracting capacity of antioxidant compounds for this species was $50 \% \mathrm{EtOH}$ $\left(10.7 \mu \mathrm{mol} \mathrm{TE}^{-1} \mathrm{DW}\right)$ in the DPPH assay. In the case of Halopithys incurva (Fig. 2d), the highest antioxidant capacity $\left(10.7 \mu \mathrm{mol} \mathrm{TE} \mathrm{g}^{-1} \mathrm{DW}\right)$ was reached in $20 \% \mathrm{MeOH}$ for $\mathrm{DPPH}$. There were no significant differences between $50 \% \mathrm{EtOH}$ and $20 \% \mathrm{MeOH}$, as well as between $\mathrm{H}_{2} \mathrm{O}$ and $100 \% \mathrm{EtOH}$ in BBM. In the case of Gracilariopsis longissima, the DPPH and ABTS assays showed no significant differences in terms of antioxidant capacity for the $20 \% \mathrm{MeOH}$ and $\mathrm{H}_{2} \mathrm{O}$ solvents (Fig. 2e).

There were no significant differences between BBM and $\mathrm{DPPH}$ in regard to $50 \% \mathrm{EtOH}$. In general, the highest antioxidant activity was found in the ethanolic solvent. Hydropuntia cornea showed the highest antioxidant capacity among the species studied, with maximum values of approximately $14.5 \mu \mathrm{mol} \mathrm{TE} \mathrm{g}{ }^{-1} \mathrm{DW}$ in the ethanolic extracts (Fig. 2f). Ulva rotundata presented lower antioxidant capacity than that in the red algae analyzed, the highest value being obtained with $50 \% \mathrm{EtOH}$ in the DPPH assay (4.46 $\mu \mathrm{mol} \mathrm{TE} \mathrm{g}^{-1}$ DW) (Fig. 2g).

In the case of L. pygmaea (Fig. 2h), using the DPPH method the antioxidant activity was slightly higher for $20 \% \mathrm{MeOH}$ and $100 \% \mathrm{EtOH}$ than that in the other 2 solvents. In the ABTS assay, the antioxidant activity in water and $100 \% \mathrm{EtOH}$ was lower than that in the other extracts (Fig. 2). However, the highest value according to BBM was found in $\mathrm{H}_{2} \mathrm{O}$.
DPPH y ABTS, el solvente que mostró el valor más alto en los ensayos fue el EtOH 50\% (para el $66.7 \%$ y $44.4 \%$, respectivamente, de las especies estudiadas). Sin embargo, con el BBM, el solvente con el mejor resultado fue EtOH 100\% (para el $44.7 \%$ de las especies). Para todas las especies de macroalgas, se encontraron interacciones significativas entre los factores "solvente" y "método" $(P<0.01)$. En el caso de Gelidium pusillum, la mayor actividad para el ensayo DPPH $\left(9.65 \mu \mathrm{mol} \mathrm{TE} \mathrm{g}^{-1} \mathrm{PS}\right)(P<0.01)$ se encontró en EtOH 50\% (Fig. 2a). Se observó la mayor capacidad antioxidante en ambos solventes etanólicos (EtOH 50\% y EtOH 100\%). Se encontró este mismo patrón para Gelidium corneum, aunque no hubo diferencias significativas entre los solventes EtOH 50\% y EtOH 100\% para el ensayo DPPH, el cual mostró mayor actividad (Fig. 2b). En el caso de P. umbilicalis (Fig. 2c), el solvente acuoso mostró resultados similares para DPPH y ABTS. La actividad antioxidante para DPPH y BBM fue también la misma para los extractos de $\mathrm{H}_{2} \mathrm{O}$, EtOH $100 \%$ y MeOH $20 \%$ ( $P>0.05)$. El solvente que mostró la mayor capacidad de extracción de compuestos antioxidantes para esta especie fue EtOH 50\% (10.7 $\mu$ mol TE g ${ }^{-1}$ PS) para el ensayo DPPH. En el caso de Halopithys incurva (Fig. 2d), se alcanzó la mayor capacidad antioxidante $\left(10.7 \mu \mathrm{mol} \mathrm{TE} \mathrm{g}^{-1} \mathrm{PS}\right)$ en $\mathrm{MeOH} 20 \%$ con el ensayo DPPH. No hubo diferencias significativas entre los solventes EtOH $50 \%$ y MeOH $20 \%$, así como entre $\mathrm{H}_{2} \mathrm{O}$ y EtOH $100 \%$ con el BBM. En el caso de Gracilariopsis longissima, DPPH y ABTS no mostraron diferencias significativas en términos de capacidad antioxidante para los solventes $\mathrm{MeOH} 20 \%$ y $\mathrm{H}_{2} \mathrm{O}$ (Fig. 2e).

No hubo diferencias significativas entre BBM y DPPH para $\mathrm{EtOH} 50 \%$. En general, se encontró la mayor actividad antioxidante en el solvente etanólico. Hydropuntia cornea mostró la mayor capacidad antioxidante entre las especies estudiadas, con valores máximos de aproximadamente $14.5 \mu \mathrm{mol} \mathrm{TE} \mathrm{g}{ }^{-1}$ PS en extractos etanólicos (Fig. 2f). Ulva rotundata presentó una menor capacidad antioxidante que las algas rojas analizadas; el valor más alto se obtuvo con EtOH

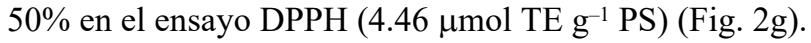

En el caso de L. pygmaea (Fig. 2h), en el ensayo DPPH la actividad antioxidante fue ligeramente superior para $\mathrm{MeOH} \mathrm{20 \%} \mathrm{y} \mathrm{EtOH} \mathrm{100 \%} \mathrm{que} \mathrm{para} \mathrm{los} \mathrm{otros} 2$ solventes. Para el método ABTS, la actividad antioxidante en $\mathrm{H}_{2} \mathrm{O}$ y EtOH $100 \%$ fue menor que en los otros extractos (Fig. 2). Sin embargo, el valor más alto según el BBM se encontró en $\mathrm{H}_{2} \mathrm{O}$.

El contenido de carbono fue significativamente diferente en las especies analizadas $(P<0.01)$, excepto para las especies del género Gelidium $(P>0.05)$. El contenido de carbono varió entre $22.2 \%$ en $U$. rotundata y $39 \%$ en el liquen marino L. pygmaea. También se encontraron valores de hasta el $30 \%$ en Gelidium pusillum, Gelidium corneum, P. umbilicalis y Gracilariopsis longissima. El contenido de nitrógeno resultó ser aún más heterogéneo $(P<0.01)$ que el de carbono. 

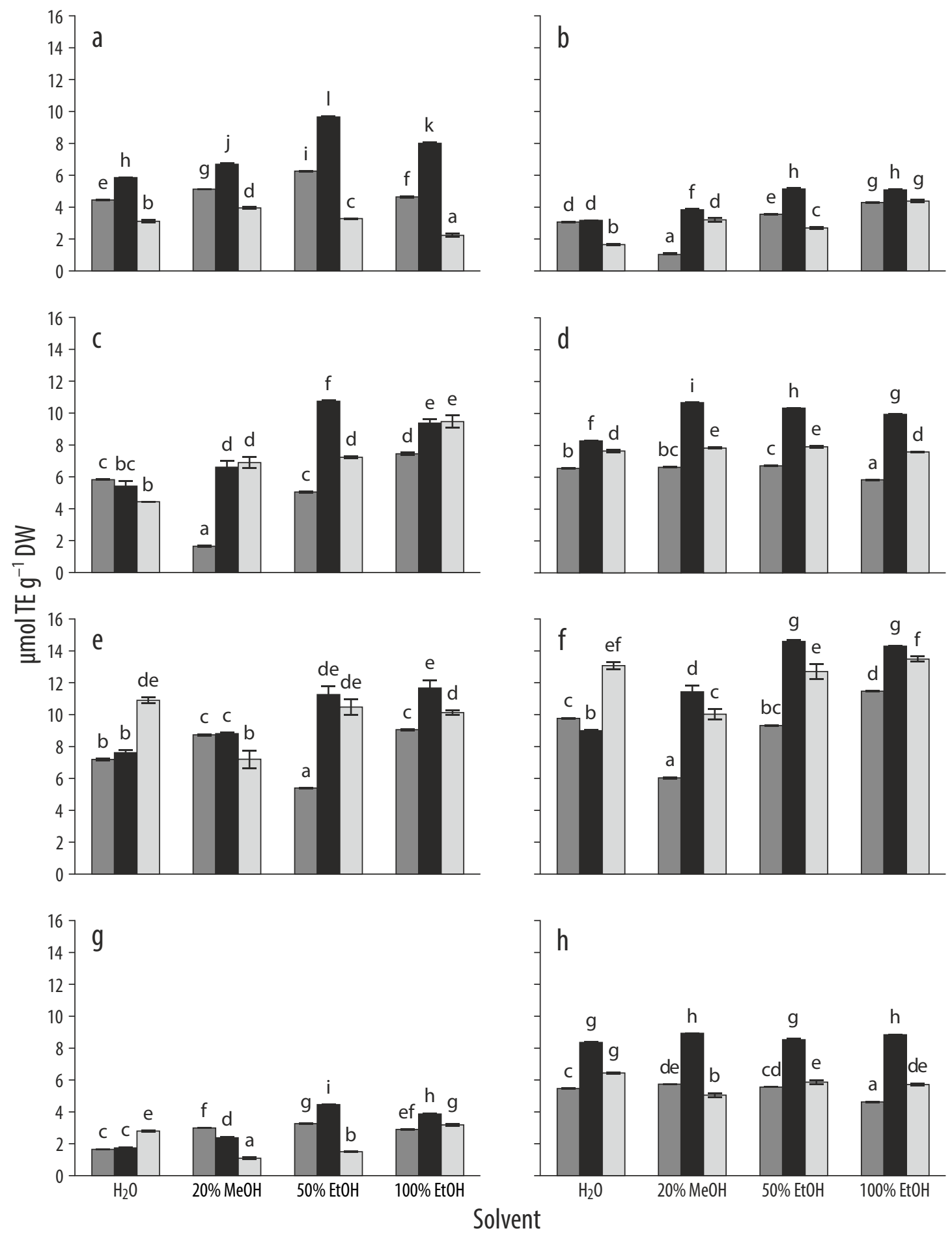

ABTS

DPPH $\square$ BBM

Figure 2. Antioxidant capacity, expressed as micromoles of Trolox equivalents per gram dry weight ( $\left.\mu \mathrm{mol} \mathrm{TE} \mathrm{g}^{-1} \mathrm{DW}\right)$, in species obtained through ABTS, DPPH, and BBM assays using different solvents. (a) Gelidium pusillum, (b) Gelidium corneum, (c) Porphyra umbilicalis, (d) Halopythis incurva, (e) Gracilariopsis longissima, (f) Hydropuntia cornea, (g) Ulva rotundata, and (h) Lichina pygmaea. Different letters indicate significant differences for solvents and methods $(P<0.05)$.

Figura 2. Capacidad antioxidante, expresada como micromoles de equivalentes Trolox por gramo de peso seco ( $\mu \mathrm{mol}$ TE $\mathrm{g}^{-1} \mathrm{DW}$ ), en las especies estimada mediante los ensayos ABTS, DPPH y BBM usando diferentes solventes. (a) Gelidium pusillum, (b) Gelidium corneum, (c) Porphyra umbilicalis, (d) Halopythis incurva, (e) Gracilariopsis longissima, (f) Hydropuntia cornea, (g) Ulva rotundata, y (h) Lichina pygmaea. Las letras diferentes indican diferencias significativas para los solventes y los métodos $(P<0.05)$. 
The carbon content was significantly different in the analyzed species $(P<0.01)$, except for the Gelidium species $(P>0.05)$. The carbon content ranged from $22.2 \%$ in $U$. rotundata to $39 \%$ in the marine lichen L. pygmaea. Values up to $30 \%$ were also found in Gelidium pusillum, Gelidium corneum, P. umbilicalis, and Gracilariopsis longissima. The nitrogen content turned out to be even more heterogeneous $(P<0.01)$ than that of carbon. The highest level was reached in L. pygmaea (6.2\%), followed by the Gelidium species (higher than 3.5\%) (Table 1). Gracilariopsis longissima and Hydropuntia cornea presented similar values. However, the species with different carbon and nitrogen content showed the same $\mathrm{C}: \mathrm{N}$ ratio (Table 1).

Total carbohydrates, expressed as percentage, showed the highest value in $50 \% \mathrm{EtOH}$ and $20 \% \mathrm{MeOH}$ (Table 2). In $20 \% \mathrm{MeOH}$, Halopithys incurva extracts showed the highest percentage of total carbohydrates among the algae studied (16.1\%), followed by Gracilariopsis longissima (14.8\%). Levels of 4-6\% were observed in Gelidium corneum, $P$. umbilicalis, and $U$. rotundata, whereas levels higher than $6 \%$ were detected in Gelidium pusillum and Hydropuntia cornea. In $20 \% \mathrm{MeOH}$, the lowest level of total carbohydrate was observed in L. pygmaea (3.28\%).

The highest lipid content was obtained with $50 \% \mathrm{EtOH}$ in 6 species. The lipid content in Halopithys incurva and Gelidium pusillum could not be quantified as there was high interference between the phenolic content and the SPV method (Sun et al. 1998). The highest values (higher than $5 \%$ ) were found for P. umbilicalis, and L. pygmaeae. The other algae presented values between $4.4 \%$ and $1.7 \%$ (Table 2). In contrast, the lowest content was obtained in P. umbilicalis with $100 \%$ EtOH.

For 3 of the 8 species studied, phenolic compounds (expressed as phloroglucinol) showed higher values for the $20 \% \mathrm{MeOH}$ solvent (Fig. 3). Significant differences among solvents were found for all the species $(P<0.01)$, except for L. pygmaea. The highest values of phenolic compounds were obtained for Gelidium pusillum (4.5-6 $\left.\mathrm{mg} \mathrm{g}^{-1} \mathrm{DW}\right)$, followed by L. pygmaea $\left(7 \mathrm{mg} \mathrm{g}^{-1} \mathrm{DW}\right)$, Halopithys incurva (4.5 $\left.\mathrm{mg} \mathrm{g}^{-1} \mathrm{DW}\right)$, and Hydropuntia cornea $\left(3 \mathrm{mg} \mathrm{g}^{-1} \mathrm{DW}\right)$ in $20 \% \mathrm{MeOH}$ (Fig. 3). The other species presented values close to or lower than $3 \mathrm{mg} \mathrm{g}^{-1}$ DW (Fig. 2).

The amount and composition of MAAs was significantly different among the species studied. Six different MAAs were detected in different proportions: mycosporine-serinol, palythine, palythinol, shinorine, porphyra-334, and asterina330. The last 5 MAAs were only present in Gelidium pusillum and $P$. umbilicalis, whereas mycosporine-serinol was present only in L. pygmaea (Table 3 ). The content of total MAAs in Gelidium pusillum was about 1.7 times higher than that of Gelidium corneum. For these UV absorbing compounds, no significant differences were found in terms of solvent used during the extraction except for $100 \% \mathrm{EtOH}$, where the content of MAAs was much lower than elsewhere.
El nivel más alto se alcanzó en L. pygmaea (6.2\%), seguido por las especies del género Gelidium (superior al 3.5\%) (Tabla 1). Gracilariopsis longissima y Hydropuntia cornea presentaron valores similares. Sin embargo, las especies con diferente contenido de carbono y nitrógeno mostraron la misma relación C:N (Tabla 1).

Los carbohidratos totales, expresados como porcentaje, mostraron el valor más alto en EtOH $50 \%$ y MeOH $20 \%$ (Tabla 2). En el último solvente, los extractos de Halopithys incurva mostraron el mayor porcentaje de carbohidratos totales entre las algas estudiadas (16.1\%), seguido de Gracilariopsis longissima (14.8\%). Se observaron niveles de 4-6\% en Gelidium corneum, P. umbilicalis y U. rotundata, mientras que se detectaron niveles superiores al $6 \%$ en Gelidium pusillum y Hydropuntia cornea. En MeOH 20\%, el nivel más bajo de carbohidratos totales se observó en L. pygmaea (3.28\%).

El mayor contenido de lípidos se obtuvo con EtOH 50\% para 6 especies. El contenido de lípidos en Halopithys incurva y Gelidium pusillum no se pudo cuantificar como consecuencia de una alta interferencia entre el contenido fenólico y el método SPV (Sun et al. 1998). Los valores más altos (superiores al 5\%) fueron encontrados para $P$. umbilicalis y L. pygmaeae. Las otras algas presentaron valores entre $4.4 \%$ y $1.7 \%$ (Tabla 2). Por el contrario, el contenido más bajo se obtuvo en $P$. umbilicalis con EtOH 100\%.

Para 3 de las 8 especies, los compuestos fenólicos (expresados como floroglucinol) mostraron valores más altos para el solvente $\mathrm{MeOH} 20 \%$ (Fig. 3). Se encontraron diferencias significativas $(P<0.01)$ entre los solventes para todas las especies, excepto para L. pygmaea. Los valores más altos de compuestos fenólicos se obtuvieron para Gelidium pusillum (4.5-6 $\mathrm{mg} \mathrm{g}^{-1} \mathrm{PS}$ ), seguido de L. pygmaea (7 $\mathrm{mg} \mathrm{g}^{-1} \mathrm{PS}$ ), H. incurva (4.5 $\left.\mathrm{mg} \mathrm{g}^{-1} \mathrm{PS}\right)$ y $\mathrm{H}$. cornea $\left(3 \mathrm{mg} \mathrm{g}^{-1} \mathrm{PS}\right)$ en extractos de $\mathrm{MeOH} 20 \%$ (Fig. 2). En las otras especies se obtuvieron valores cercanos o inferiores a $3 \mathrm{mg} \mathrm{g}^{-1} \mathrm{PS}$.

La cantidad y composición de AAM fue significativamente diferente entre las especies estudiadas. Se detectaron 6 AAM diferentes en proporciones distintas: micosporinaserinol, palitina, palitinol, shinorina, porphyra-334 y asterina330. Los últimos 5 AAM sólo se encontraron en Gelidium pusillum y $P$. umbilicalis, mientras que micosporina-serinol se cuantificó excluvisamente en L. pygmaea (Tabla 3). El contenido de AAM totales en Gelidium pusillum fue aproximadamente 1.7 veces mayor que en Gelidium corneum. Para estos compuestos, no se encontraron diferencias significativas en términos de solvente empleado durante la extracción excepto para EtOH 100\%, donde el contenido de AAM fue mucho menor que para los demás solventes utilizados. El segundo AAM dominante fue el palitinol, que se detectó en todas las especies excepto en L. pygmaeae. El aminoácido palitina se observó en todas las especies excepto en el liquen marino y en Gracilariopsis longissima. Como aminoácido exclusivo, micosporina-serinol sólo se encontró en 

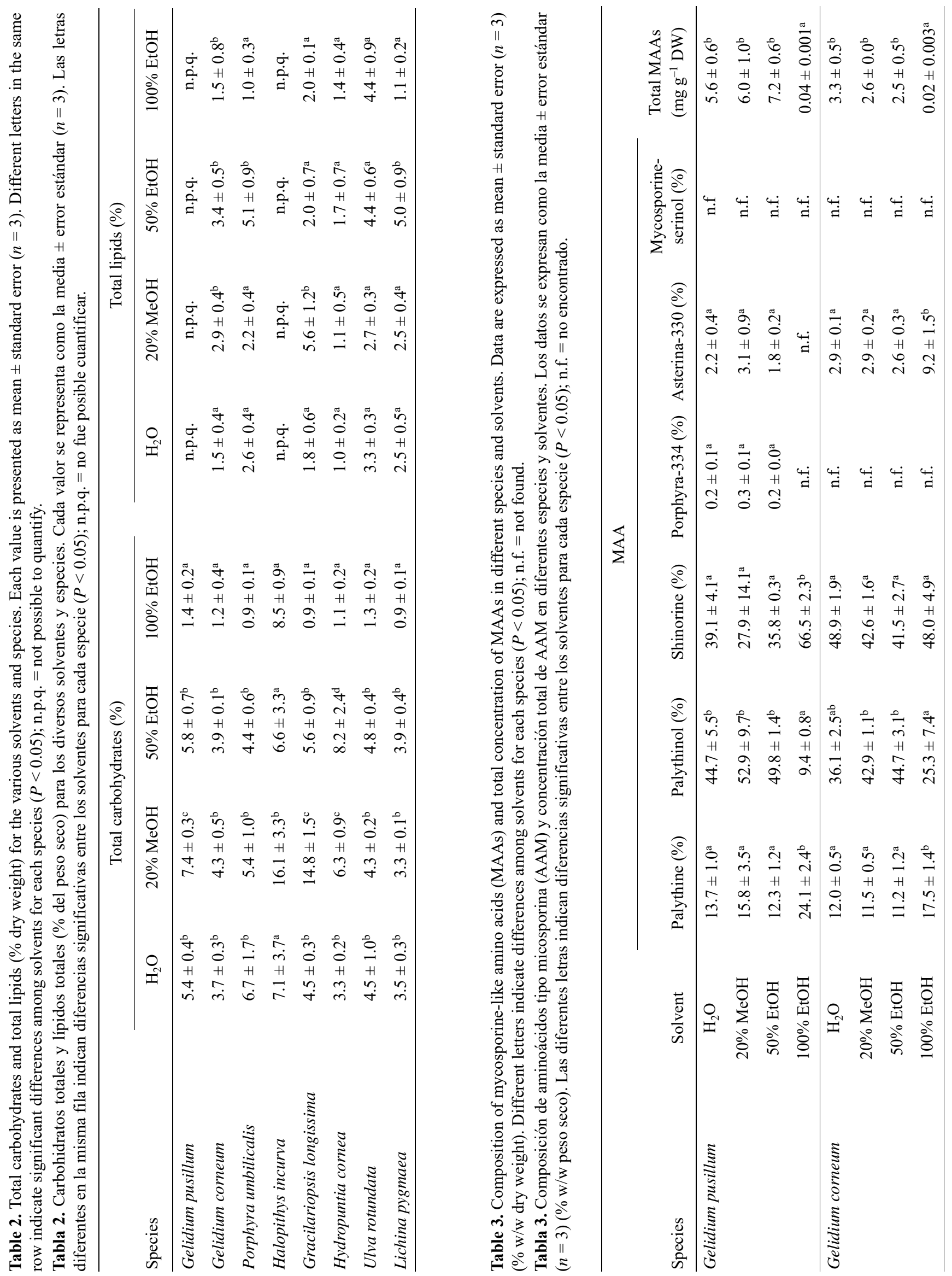


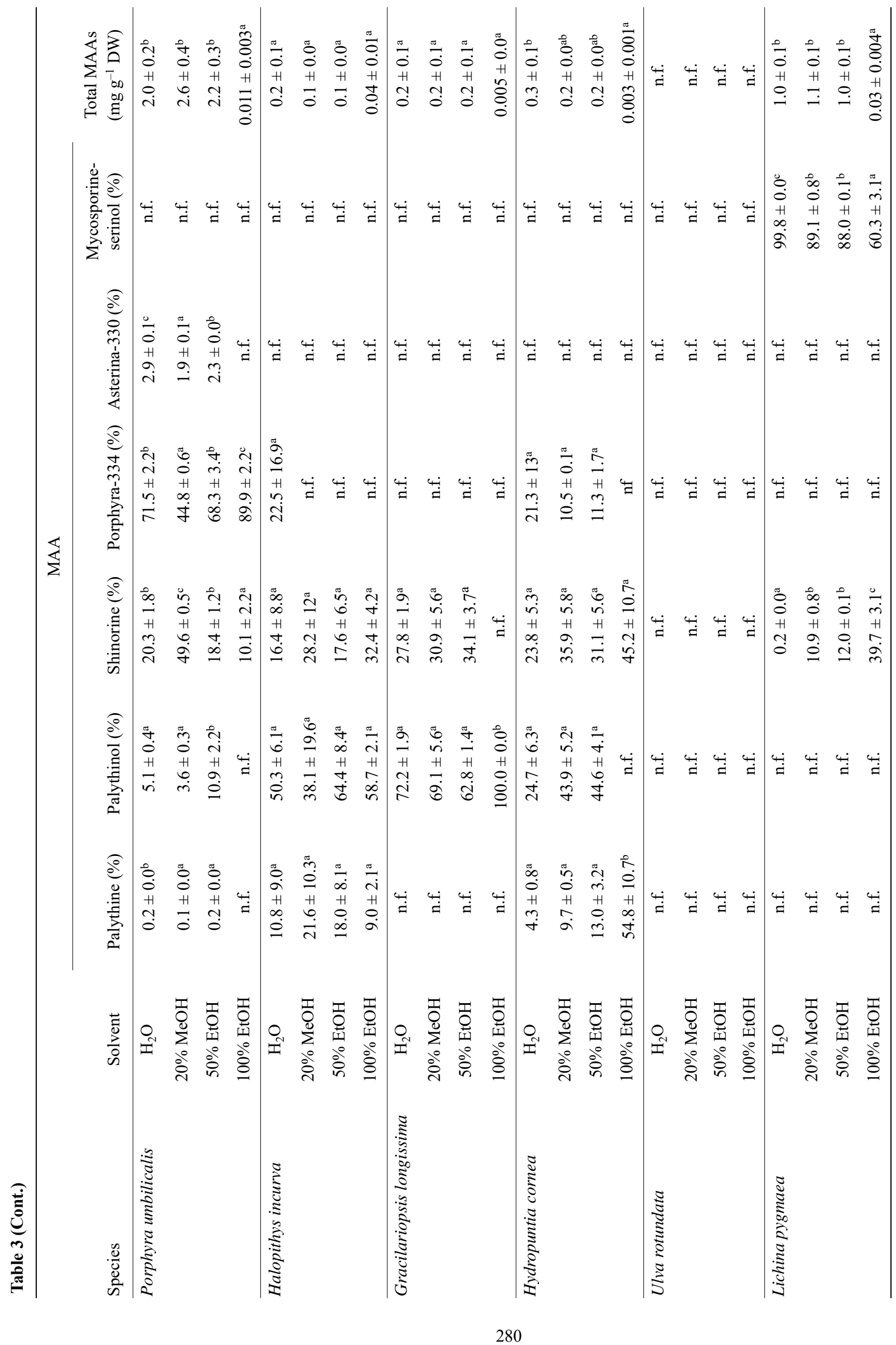




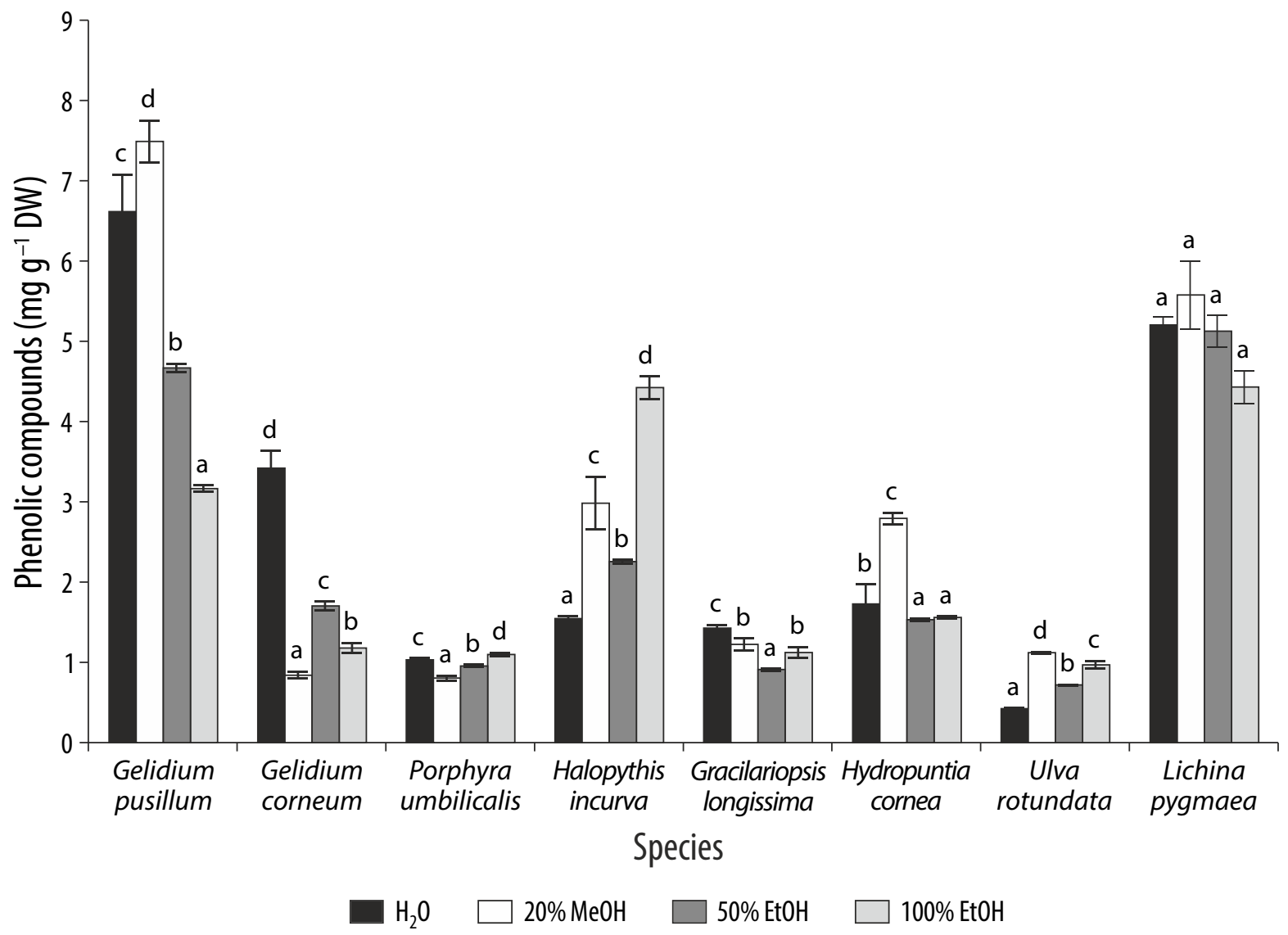

Figure 3. Phenolic compounds ( $\mathrm{mg} \mathrm{g}^{-1}$ dry weight) in different solvents for each species. Differences among solvents are indicated by different letters for each species $(P<0.05)$. Data are expressed as mean \pm standard error $(n=3)$.

Figura 3. Compuestos fenólicos ( $\mathrm{mg} \mathrm{g}^{-1}$ de peso seco) en diferentes solventes para cada especie. Las diferencias entre los solventes para cada especie se indican con letras diferentes $(P<0.05)$. Los datos se expresan como media \pm error estándar $(n=3)$.

The second dominant MAA was palythinol, which was detected in all species except in L. pygmaeae. Palythine was observed in all species except in the marine lichen and Gracilariopsis longissima. In contrast, mycosporine-serinol was only found in L. pygmaeae, whereas porphyra-334 was found in Gelidium pusillum, P. umbilicalis, and Hydropuntia cornea. Finally, asterina-330 was detected in both Gelidium species and in P. umbilicalis.

The antioxidant capacity in Gelidium pusillum was correlated with the lipid content in the ABTS assay $(P<0.05$; $r=0.98 ; n=12)$, and with the total carbohydrate content $(P<0.05 ; r=0.98 ; n=12)$ and the MAA asterina-330 $(P<0.05 ; r=0.67 ; n=9)$ when BBM was used. However, in the case of Gelidium corneum, in the ABTS assay, the antioxidant capacity was related to only total MAAs $(P<0.01$; $r=0.78 ; n=12)$. For P. umbilicalis, in the ABTS assay, the antioxidant capacity was correlated with the phenolic content $(P<0.01 ; r=0.99)$, the MAA shinorine $(P<0.01 ; r=0.83$; $n=12)$, porphyra-334 $(P<0.01 ; r=0.92 ; n=12)$, and total MAAs $(P<0.01 ; r=0.91 ; n=12)$. In Halopithys incurva
L. pygmaeae. Porphyra-334 se encontró en sólo 3 de las especies (Gelidium pusillum, P. umbilicalis y Hydropuntia cornea). Finalmente, se detectó asterina-330 en ambas especies del género Gelidium y en P. umbilicalis.

La capacidad antioxidante en Gelidium pusillum se correlacionó con el contenido de lípidos en el ensayo ABTS $(P<0.05 ; r=0.98 ; n=12)$, y con el contenido de carbohidratos $(P<0.05 ; r=0.98 ; n=12)$ y el aminoácido asterina-330 $(P<0.05 ; r=0.67 ; n=9)$ para el BBM. Sin embargo, en el caso de Gelidium corneum, la capacidad antioxidante estuvo relacionada, en el ensayo ABTS, con los AAM totales $(P<0.01 ; r=0.78 ; n=12)$. Para $P$. umbilicalis, en el ensayo ABTS, la capacidad antioxidante se correlacionó con el contenido fenólico $(P<0.01 ; r=0.99)$, el aminoácido shinorina $(P<0.01 ; r=0.83 ; n=12)$, el aminoácido porphyra-334 $(P<0.01 ; r=0.92 ; n=12)$ y los AAM totales $(P<0.01$; $r=0.91 ; n=12)$. En Halopithys incurva $(P<0.01 ; r=0.80$; $n=12)$ y $U$. rotundata $(P<0.01 ; r=0.72 ; n=12)$, el contenido fenólico se correlacionó positivamente con la capacidad antioxidante. En Gracilariopsis longissima, la capacidad 
$(P<0.01 ; r=0.80 ; n=12)$ and $U$. rotundata $(P<0.01$; $r=0.72 ; n=12)$, the phenolic content correlated positively with the antioxidant capacity. In Gracilariopsis longissima, the antioxidant capacity measured with BBM correlated with lipids $(P<0.01 ; r=0.80 ; n=12)$. The antioxidant capacity in Hydropuntia cornea correlated with the MAA palythinol $(P<0.05 ; r=0.82)$ in the DPPH assay. Finally, the antioxidant capacity in L. pygmaea was correlated with the phenolic content $(P<0.05 ; r=0.969 ; n=12)$ and total carbohydrates $(P<0.01 ; r=0.89 ; n=12)$ in the ABTS assay. The MAA shinorine was correlated with antioxidant activity $(P<0.01$; $r=0.80 ; n=12)$ in the DDPH assay.

Correlation between antioxidant activity was found among the 3 methods: ABTS-DPPH $(P<0.01 ; r=0.859$; $n=36)$, ABTS-BBM $(P<0.01 ; r=0.825 ; n=36)$, and DPPH-BBM $(P<0.01 ; r=0.841 ; n=36)$.

The quantity of soluble carbohydrates was correlated with antioxidant activity measured with ABTS $(P<0.01 ; r=0.28$; $n=96)$ and DPPH $(P<0.01 ; r=0.30 ; n=96)$. The lipid content was related to antioxidant activity in Gracilariopsis longissima with ABTS $(P<0.01 ; r=0.25 ; n=96)$ and with $\operatorname{BBM}(P<0.01 ; r=0.99 ; n=96)$.

The phenolic compound content was correlated with the ABTS $(P<0.05 ; r=0.21 ; n=96)$ and DPPH $(P<0.01$; $r=0.28 ; n=96)$ methods. Finally, total MAA levels were correlated with the 2 antioxidant methods used: ABTS $(P<0.05 ; r=0.408 ; n=36)$ and DPPH $(P<0.05 ; r=0.431$; $n=36)$.

\section{DISCUSSION}

In general, it is noteworthy that in the aqueous medium $\left(\mathrm{H}_{2} \mathrm{O}\right)$, the antioxidant capacity observed by the DPPH and ABTS methods was similar in $55 \%$ of the species analyzed; an explanation for this result is that both methods have the same action mechanism. Between these 2 antioxidant assays, the solvent with the highest antioxidant capacity extraction was $50 \%$ EtOH for $44 \%$ and $56 \%$ of the species studied with the ABTS and DPPH methods, respectively. These results are in agreement with those obtained by Plaza et al. (2010). However, for the BBM assay, the best solvent was $100 \% \mathrm{EtOH}$, probably related to the fact that this method is suitable for the determination of antioxidant compounds in a lipophilic medium.

Another important difference between the assays is that the ABTS radical can be dissolved both in organic and aqueous medium; therefore, the antioxidant activity can be measured considering the hydrophilic or lipophilic nature of the compounds in the sample (Wojdylo et al. 2007). On the contrary, the DPPH radical can only be measured in an organic medium, limiting the interpretation of the antioxidant capacity of hydrophilic compounds present in the extracts (Surveswaran et al. 2007). On the other hand, a synergism among different bioactive compounds may also be occurring in our extracts. antioxidante cuantificada con el BBM se correlacionó con los lípidos totales $(P<0.01 ; r=0.80 ; n=12)$. La capacidad antioxidante en Hydropuntia cornea se correlacionó con el aminoácido palitinol $(P<0.05 ; r=0.82)$ en el ensayo DPPH. Por último, la capacidad antioxidante en L. pygmaea se correlacionó con el contenido de compuestos fenólicos $(P<0.05$; $r=0.969 ; n=12)$ y carbohidratos totales $(P<0.01 ; r=0.89$; $n=12)$ en el ensayo ABTS. El aminoácido shinorina se correlacionó con la actividad antioxidante $(P<0.01 ; r=$ $0.80 ; n=12$ ) en el ensayo DDPH.

Se encontró correlación entre la actividad antioxidante entre los 3 métodos empleados: ABTS-DPPH $(P<0.01$; $r=0.859 ; n=36)$, ABTS-BBM $(P<0.01 ; r=0.825 ; n=36)$ y DPPH-BBM $(P<0.01 ; r=0.841 ; n=36)$.

La cantidad de carbohidratos solubles se correlacionó con las actividades antioxidantes medidas con los ensayos ABTS $(P<0.01 ; r=0.28 ; n=96)$ y DPPH $(P<0.01 ; r=0.30$; $n=96$ ). El contenido de lípidos se relacionó con la actividad antioxidante en Gracilariopsis longissima con el método ABTS $(P<0.01 ; r=0.25 ; n=96)$ y el BBM $(P<0.01$; $r=0.99 ; n=96)$.

El contenido de compuestos fenólicos se correlacionó con los métodos ABTS $(P<0.05 ; r=0.21 ; n=96)$ y DPPH $(P<0.01 ; r=0.28 ; n=96)$. Finalmente, los niveles de AAM totales también se correlacionaron con los métodos ABTS $(P<0.05 ; r=0.408 ; n=36)$ у DPPH $(P<0.05 ; r=0.431$; $n=36)$.

\section{DisCUSIÓN}

En general, cabe destacar que para el solvente acuoso $\left(\mathrm{H}_{2} \mathrm{O}\right)$, la capacidad antioxidante de los métodos DPPH y ABTS fue similar en el $55 \%$ de las especies estudiadas. Este resultado podría explicarse debido a que ambos métodos se rigen por el mismo mecanismo de acción. Entre estos 2 ensayos antioxidantes, el solvente con mayor capacidad de extracción de antioxidantes fue el EtOH 50\% para el 44\% y $56 \%$ de las especies estudiadas con los métodos ABTS y $\mathrm{DPPH}$, respectivamente. Estos resultados concuerdan con los obtenidos por Plaza et al. (2010). Sin embargo, para el BBM, el mejor solvente fue EtOH 100\%, probablemente relacionado con el hecho de que este método es adecuado para la determinación de compuestos antioxidantes en un medio estrictamente lipofílico.

Otra diferencia importante entre los ensayos empleados es que el radical ABTS puede solubilizarse tanto en solventes orgánicos como en solventes acuosos, por lo que se puede medir la actividad antioxidante considerando la naturaleza hidrófila o lipofílica de los compuestos de la muestra (Wojdylo et al. 2007). Por el contrario, el radical DPPH sólo puede medirse en un medio orgánico, limitando la interpretación de la capacidad antioxidante de los compuestos hidrofílicos presentes en los extractos (Surveswaran et al. 2007). Por otra parte, no se descarta el sinergismo que pueda acontecer entre los diferentes compuestos en los extractos. 
In order to select a macroalgal species it is necessary to develop appropriate, quick, cost-efficient, and environmentally friendly methods of extraction that aim to isolate biologically active compounds of interest without loss of the activity. In numerous studies, the most common solvents for the extraction of antioxidants include water, ethanol, methanol, and aqueous mixtures thereof (Alam et al. 2013). These have good polarity and are therefore preferably used for extraction of polar compounds such as phenolic compounds or MAAs, among others. Ultimately, the polarity of the extracting solvent as well as the technique of extraction have a critical effect on the extraction yield (López et al. 2011). Methanol, however, should be discarded for cosmetic applications due to its toxicity.

Among the radical scavenging assays used in this study, the ABTS and DPPH methods are the fastest, simplest (involving fewer steps), and have a lower cost compared to $\mathrm{BBM}$ and other methods. In addition, BBM requires many reagents, a long time, and an advanced level of technology, and the result only provides a vision of lipophilic antioxidants. The ABTS assay is the only method tested in this study that is applicable to both hydrophilic and lipophilic antioxidants (Alam et al. 2013), so its use is justified in studies where it is intended to have an integrated vision of the extract. We found a positive correlation between the DPPH and ABTS methods, between ABTS and BBM, and between $\mathrm{BBM}$ and DPPH. A positive correlation between the DPPH and ABTS methods was also found by Floegel et al. (2011), probably because these assays are based on electron transfer, while BBM is based on a mechanism of hydrogen atom transfer (Huang et al. 2005).

In our study, in general, the antioxidant activity in the macroalgae and marine lichen analyzed is high

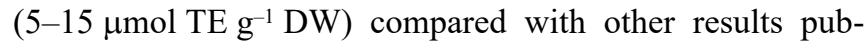
lished for several microalgae $\left(7-11 \mu \mathrm{mol} \mathrm{TE} \mathrm{g} \mathrm{g}^{-1} \mathrm{DW}\right)$ and

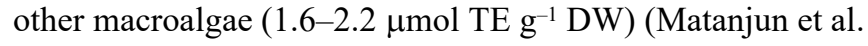
2008). This could be explained by the fact that most species analyzed in other studies are subjected to stressors in their habitat or in the culture system. The increase in stress provokes an activation of both enzymatic and nonenzymatic antioxidant substances (Stengel et al. 2011). Regarding the effect of type of solvent on the antioxidant activity, Yuan et al. (2005) estimated antioxidant activity related to polyphenols in Palmaria palmata and obtained the highest levels of these substances using methanol as extractor. Hydrophilic constituents are extracted with polar solvents such as water, methanol, or ethanol. O'Sullivan et al. (2011) used methanol and water to extract bioactive compounds (antioxidants) from different brown algae, Fucus being the genus with the highest antioxidant activity. The results of this study are consistent with the results found by Sarikurkcu et al. (2009) in extracts of terrestrial plants, in which a strong correlation between the polarity of the extracts and their antioxidant potential was observed. The most polar extracts showed a greater potential for capturing free radicals. To have a high biotechnological
Para seleccionar una especie es necesario desarrollar métodos de extracción apropiados, rápidos, rentables y respetuosos con el medio ambiente, y que permitan aislar compuestos biológicamente activos sin que se origine una pérdida de la bioactividad. En numerosos estudios, los solventes más comunes para la extracción de antioxidantes incluyen agua, etanol, metanol y mezclas acuosas de los mismos (Alam et al. 2013). Éstos tienen buena polaridad y por lo tanto son favorables para ser utilizados para la extracción de compuestos polares tales como compuestos fenólicos o AAM, entre otros. En última instancia, la polaridad del solvente así como la técnica de extracción tienen un efecto crítico sobre el rendimiento de extracción (López et al. 2011). El metanol, sin embargo, debería de ser descartado para aplicaciones cosméticas debido a su toxicidad.

Entre los ensayos utilizados en este estudio para el barrido de radicales, los métodos ABTS y DPPH son los más rápidos, simples (no incluyen muchos pasos) y tienen un menor coste en comparación con el BBM. Además, el BBM requiere muchos más reactivos, mucho más tiempo y más recursos técnicos para la realización del ensayo, y el resultado sólo proporciona una visión de los antioxidantes que se encuentren en la matriz lipofílica. El ensayo ABTS es el único método evaluado en este estudio que es aplicable tanto a antioxidantes hidrofílicos como lipofílicos (Alam et al. 2013), por lo que su uso es justificado en otros estudios en los que se pretende obtener una visión integrada del extracto. Se encontró una correlación positiva entre los métodos DPPH y ABTS, entre ABTS y BBM, y entre BBM y DPPH. Floegel et al. (2011) también encontraron una correlación positiva entre los métodos DPPH y ABTS. Esto se explica por el hecho de que estos ensayos se fundamentan en el mismo mecanismo de reacción (en la transferencia de electrones), mientras que el BBM se fundamenta en un mecanismo de transferencia de átomos de hidrógeno (Huang et al. 2005).

En nuestro estudio, en general, la actividad antioxidante en el liquen marino y las macroalgas analizadas $(5-15 \mu \mathrm{mol}$ TE $\mathrm{g}^{-1} \mathrm{PS}$ ) es alta en comparación con otros resultados publicados para varias microalgas (7-11 $\mu$ mol TE $\left.\mathrm{g}^{-1} \mathrm{PS}\right)$ y otras

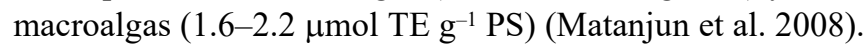
Esto podría ser explicado debido a que la mayoría de las especies analizadas en otros estudios se someten a diferentes estresores en el sistema de cultivo. El aumento del estrés provoca una activación de las sustancias antioxidantes enzimáticas y no enzimáticas (Stengel et al. 2011). Acerca del efecto del tipo de solvente en la actividad antioxidante, Yuan et al. (2005) estimaron la actividad antioxidante relacionada con los polifenoles de Palmaria palmata, obteniendo niveles más altos de estas sustancias usando metanol como extractor. Los componentes hidrófilos se extraen con solventes polares tales como agua, metanol o etanol. O'Sullivan et al. (2011) utilizaron metanol y agua para extraer compuestos bioactivos (antioxidantes) de diferentes algas pardas, siendo el género Fucus el que presentó mayor actividad antioxidante. Los resultados de este estudio concuerdan con los resultados 
production of bioactive compounds, potentially cultivable species should ideally present low levels of water and high levels of organic matter. The analyzed red algae have much higher internal water levels and lower organic matter levels than L. pygmaea and U. rotundata (Chlorophyta). The latter 2 species presented low levels of internal water resulting in low FW/DW values. Holdt and Kraan (2011) reported a similar percentage of water in Ulva species (78-80\%) compared to red macroalgae $(72-85 \%)$. This depends on the characteristics of the species itself, as well as on the zone occupied in the ecosystem. The ash and organic matter content in the different species harvested from the natural environment also depends on the phylum, the geographical origin, and seasonal, environmental and physiological variables. In any case, minerals in the ash in algae are also interesting from a nutrition point of view.

Extraction of biologically active compounds from algal biomass is not selective. The extract is a mixture of different compounds. The factors that influence the composition and the activity of algal extracts depend on the species, environmental conditions, season of the year, age, geographical location, and processing technologies (Kadam et al. 2013). The environmental stress to which algae are exposed (e.g., irradiance, temperature, desiccation, osmotic stress) leads to the formation of free radical and oxidizing agents that provoke photodynamic damage (Gupta and Abu-Ghannam 2011).

Marine macroalgae are a source of bioactive compounds with different biological activities that are not found in terrestrial plants. Seaweeds contain polysaccharides (polymers of monosaccharides linked together by glycosidic bonds) that have numerous biotechnological applications in products such as stabilizers, thickeners, emulsifiers, food, beverages, etc. The total carbohydrate concentrations in the seaweed species of interest range from $4 \%$ to $76 \% \mathrm{DW}$. Carbohydrates can be chemically separated into soluble and insoluble fractions. The amount of soluble carbohydrates varies between taxa but, according to the results of this study, it is highest in red algae. The 2 species that showed the highest values of carbohydrates are Gracilariopsis longissima and Halopithys incurva (16.1\% and $14.8 \%$, respectively) in the methanol:water extract $(20 \% \mathrm{MeOH})$. These species have been shown to have a high growth rate in integrated multitrophic aquaculture systems. At a stocking density of $6 \mathrm{~g} \mathrm{FW} \mathrm{L}^{-1}$, a biomass production of 22-29 $\mathrm{g} \mathrm{DW} \mathrm{m}^{-2} \mathrm{~d}^{-1}$ was found (Viera et al. 2011). A growth rate of $10-16 \% \mathrm{~d}^{-1}$ was reported for G. longissima and H. incurva (Robledo et al. 2014). In extensive aquaculture ponds, the growth rate of G. longissima was $9 \% \mathrm{~d}^{-1}$ (Hernández et al. 2006). Halopithys incurva has been cultivated in fishpond effluents at $8 \mathrm{~g} \mathrm{FW} \mathrm{L}^{-1}$ with a production of about $5 \mathrm{~g} \mathrm{DW} \mathrm{m}^{-2} \mathrm{~d}^{-1}$ and nitrogen uptake efficiency of $90-99 \%$; however, at $6 \mathrm{~g} \mathrm{FW} \mathrm{L}^{-1}$, the average biomass productivity was 16-19 $\mathrm{g} \mathrm{DW} \mathrm{m}^{-2} \mathrm{~d}^{-1}$ (Viera et al. 2011).

Polyphenols were detected in all the analyzed species, but were higher in the red algae Gelidium pusillum and encontrados por Sarikurkcu et al. (2009) en extractos de plantas terrestres, en los que se observó una fuerte correlación entre la polaridad de los extractos y su potencial antioxidante. Los extractos más polares mostraron el mayor potencial para la neutralización de radicales libres. Desde un punto de vista biotecnológico, para tener una alta producción, lo idóneo es que las especies potencialmente cultivables presenten bajos niveles de agua y altos niveles de materia orgánica. Las algas rojas analizadas en este trabajo presentaron niveles mucho más altos de agua interna y menor materia orgánica que $L$. pygmaea y $U$. rotundata (Chlorophyta). Estas 2 especies presentaron bajos niveles de agua interna en cuanto a la relación PF/PS. Holdt y Kraan (2011) encontraron un porcentaje similar de agua en las especies de Ulva (78-80\%) en comparación con las macroalgas rojas (72-85\%). Esto depende de las características propias de la especie, así como de la zona que ocupen en el ecosistema. El contenido de cenizas y de materia orgánica en las diferentes especies obtenidas del entorno natural es dependiente también del filo, del origen geográfico y de las variables estacionales, ambientales y fisiológicas en el que se encuentren. En cualquier caso, los minerales contenidos en la ceniza de algas también presentan interés desde el punto de vista nutricional.

La extracción de compuestos biológicamente activos de la biomasa de algas no es selectiva. El extracto en su conjunto es una mezcla de diferentes compuestos. Los factores que influyen en la composición y la actividad de los extractos de algas dependen de las especies empleadas, las condiciones ambientales donde se recolectaron, la estación del año, la edad, la ubicación geográfica y las tecnologías de extracción empleadas (Kadam et al. 2013). El estrés ambiental al que están sometidas las algas (e.g., irradiancia, temperatura, desecación, estrés osmótico, etc.) conduce a la formación de radicales libres y agentes oxidantes que pueden provocar daño fotodinámico (Gupta y Abu-Ghannam 2011).

Las macroalgas marinas son una fuente de compuestos bioactivos con diferentes actividades biológicas que habitualmente no se encuentran en plantas terrestres. Las algas contienen polisacáridos (polímeros de monosacáridos unidos entre sí por enlaces glicosídicos) con numerosas aplicaciones biotecnológicas en productos tales como estabilizantes, espesantes, emulsionantes, alimentos, bebidas, etc. Las concentraciones totales de carbohidratos en las especies de algas marinas de interés oscilan entre el $4 \%$ y el $76 \%$ PS. Los carbohidratos pueden separarse químicamente en fracciones solubles e insolubles. La cantidad de carbohidratos solubles varía entre los taxones, siendo más alta en las algas rojas de acuerdo a los resultados obtenidos en este estudio. Las 2 especies que mostraron los mayores valores de carbohidratos son Gracilariopsis longissima y Halopithys incurva (16.1\% y $14.8 \%$, respectivamente) en $\mathrm{MeOH} 20 \%$. Estas especies han demostrado una alta tasa de crecimiento en sistemas de acuicultura multitrófica integrada. En cultivos a una densidad de $6 \mathrm{~g} \mathrm{PF} \mathrm{L}^{-1}$, se encontró una alta producción de biomasa (22-29 $\mathrm{g} \mathrm{PS} \mathrm{m}^{-2} \mathrm{~d}^{-1}$ ) (Viera et al. 2011). También se observó 
Halopithys incurva and in the marine lichen L. pygmaeae than in the other species. The lowest level of polyphenols was found in the green alga $U$. rotundata. In $44 \%$ of the species studied, the methanol:water extract $(20 \% \mathrm{MeOH})$ was the most efficient for polyphenol extraction. This agrees with the results obtained by López et al. (2011) who describe a more efficient extraction of polyphenols in methanol or ethanol than in water; however, the water extract for the brown alga Stypocaulon scoparium showed both the highest activity and phenolic contents compared to the $50 \%$ methanol, $100 \%$ methanol or $100 \%$ ethanol extracts used in that study. López et al. (2011) observed that the levels of phenolic compounds could be 3 times different depending on the extraction method used. In this study, the content of phenolic compounds in some of the red algae and in the lichen studied are as high as in brown macroalgae, the microalgal group with the highest reported level of polyphenols (Connan et al. 2006, Stengel et al. 2011). For example, the content of phenols in the different solvents was $3.2-6.1 \mathrm{mg} \mathrm{g}^{-1} \mathrm{DW}$ for Gelidium pusillum, $1.5-4.4 \mathrm{mg} \mathrm{g}^{-1} \mathrm{DW}$ for Halopithys incurva, $1.5-2.8 \mathrm{mg} \mathrm{g}^{-1} \mathrm{DW}$ for Hydropuntia cornea, and 4.4-5.2 $\mathrm{mg} \mathrm{g}^{-1} \mathrm{DW}$ for L. pygmaea. Güenaga (2011) previously reported high levels of phenols in Halopithys incurva. In addition, sulphated phenols and bromophenols have been detected in several species of red macroalgae (Zhao et al. 2004). Among the macroalgae, Rhodophyta possess the highest abundance of halogenated phenols (mainly brominated and chlorinated) with antioxidant, antimicrobial, anticancer, antidiabetic, and antithrombotic effects. The results obtained for phenolic compounds in this study agree with the values found by other authors. Souza et al. (2011) reported values of 1.1 and $0.89 \mathrm{mg}$ GAE (gallic acid equivalents) $\mathrm{g}^{-1}$ DW for Gracilaria birdiae and Hydropuntia cornea, respectively. For Porphyra sp., Kuda et al. (2005) obtained $0.88 \mathrm{mg}$ $\mathrm{CE}$ (catechin equivalents) $\mathrm{g}^{-1} \mathrm{DW}$ in ethanolic solvent. For Gracilariopsis tenuifrons, Zubia et al. (2014) reported values of 1-1.4 mg PGE (phloroglucinol equivalents) $\mathrm{g}^{-1} \mathrm{DW}$ for phenols extracted with methanolic solvents.

The absorption spectra of the extracts presented characteristic peaks in the UVB $(310 \mathrm{~nm})$ and UVA $(330-334 \mathrm{~nm})$ region of the spectra (data not shown). This interval corresponds to absorption by photoprotective molecules (MAAs) present in some marine organisms, such as red algae and lichens. In $U$. rotundata, no absorption in this spectral range was found and no MAAs were detected by HPLC. The maximal absorption at $310 \mathrm{~nm}$ in the $L$. pygmaeae extracts corresponds to the oxo-MAA mycosporine-serinol, whereas the absorption peaks with maximum around 320-334 nm are related to imino-MAAs of red algae (palythine, palythinol, shinorine, porphyra-334, and asterina-330).

In our study, Gelidium pusillum and G. corneum presented palythinol and shinorine as the main MAAs. In general for all the studied species, the content of MAAs was much lower than elsewhere using $100 \% \mathrm{EtOH}$ as solvent. una tasa de crecimiento de $10-16 \% \mathrm{~d}^{-1}$ para G. longissima y $H$. incurva (Robledo et al. 2014). En sistemas de acuicultura extensiva, G. longissima mostró un crecimiento del $9 \% \mathrm{~d}^{-1}$ (Hernández et al. 2006). Por último, $H$. incurva también se ha cultivado en efluentes de piscicultura a una densidad de $8 \mathrm{gPF} \mathrm{L}^{-1}$ con una producción de aproximadamente $5 \mathrm{~g} \mathrm{PS} \mathrm{m}^{-2} \mathrm{~d}^{-1} \mathrm{y}$ una eficiencia de asimilación de nitrógeno de 90-99\%; sin embargo, a una densidad de cultivo de $6 \mathrm{~g} \mathrm{PF} \mathrm{L}^{-1}$, la productividad promedio de la biomasa en los distintos tratamientos fue de $16-19 \mathrm{~g} \mathrm{PS} \mathrm{m}^{-2} \mathrm{~d}^{-1}$ (Viera et al. 2011).

Se detectaron polifenoles en todas las especies analizadas, siendo mayor en las algas rojas Gelidium pusillum y Halopithys incurva y en el liquen marino L. pygmaeae con respecto a las otras especies. El nivel más bajo de polifenoles se encontró en la alga verde $U$. rotundata. En el $44 \%$ de las especies estudiadas, el solvente $\mathrm{MeOH} 20 \%$ fue el más eficiente para la extracción de estas sustancias. Esto coincide con los resultados obtenidos por López et al. (2011), quienes describieron una extracción más eficiente en metanol o etanol que en agua; sin embargo, el extracto obtenido con el solvente $\mathrm{H}_{2} \mathrm{O}$ para el alga parda Stypocaulon scoparium mostró el mayor contenido fenólico en comparación con los solventes $\mathrm{MeOH} 50 \%$, MeOH $100 \%$ y EtOH $100 \%$ empleados en ese estudio. López et al. (2011) afirmaron que los niveles de compuestos fenólicos pueden variar hasta 3 veces dependiendo del método de extracción utilizado. En este estudio, el contenido de compuestos fenólicos en algunas de las algas rojas y en el liquen es tan alto como en macroalgas pardas, el grupo de macroalgas con el mayor nivel reportado de polifenoles (Connan et al. 2006, Stengel et al. 2011). Por ejemplo, el contenido de fenoles en los diferentes solventes fue de $3.2-6.1 \mathrm{mg} \mathrm{g}^{-1}$ PS para Gelidium pusillum, $1.5-4.4 \mathrm{mg} \mathrm{g}^{-1} \mathrm{PS}$ para Halopithys incurva, $1.5-2.8 \mathrm{mg} \mathrm{g}^{-1}$ PS para Hydropuntia cornea y 4.4-5.2 $\mathrm{mg} \mathrm{g}^{-1} \mathrm{PS}$ para L. pygmaea. El alto nivel de fenoles en Halopithys incurva ya ha sido reportado previamente por Güenaga (2011). Además, se han detectado fenoles sulfatados y bromados en varias especies de macroalgas rojas (Zhao et al. 2004). Entre las macroalgas, la división Rhodophyta es la que posee la mayor abundancia de fenoles halogenados (bromados y clorados fundamentalmente) con probados efectos antioxidantes, antimicrobianos, anticancerígenos, antidiabéticos y antitrombóticos. Los resultados obtenidos en este estudio para los compuestos fenólicos concuerdan con los valores encontrados por otros autores. Souza et al. (2011) obtuvieron valores de 1.1 y $0.89 \mathrm{mg}$ EAG (equivalentes de ácido gálico) $\mathrm{g}^{-1}$ PS para Gracilaria birdiae e Hydropuntia cornea, respectivamente. Para Porphyra sp., Kuda et al. (2005) obtuvieron $0.88 \mathrm{mg}$ EC (equivalentes de catequinas) $\mathrm{g}^{-1}$ PS en solvente etanólico. Para Gracilariopsis tenuifrons, Zubia et al. (2014) encontraron valores de 1-1.4 mg EF (equivalentes de floroglucinol) $\mathrm{g}^{-1}$ PS para los fenoles extraídos con solventes metanólicos.

Los espectros de absorción de los extractos presentaron picos característicos en la región UVB $(310 \mathrm{~nm})$ y UVA 
This may be explained by the lower polarity of pure ethanol to interact with the hydrophobic part of amino acids and peptides. MAAs can be different among the species due to environmental conditions (UV radiation, nitrogen availability, etc.) in which the specimens grow. The content of total MAAs in G. pusillum was about 1.7 times higher than that of G. corneum. The latter species is found in the lower part of the intertidal zone and in subtidal areas, whereas the former is found in the upper part, where the daily integrated irradiance is higher (Figueroa and Gómez 2001). MAAs are regulated by both irradiance and light quality, and also by nitrogen availability (Barufi et al. 2011). Torres et al. (2015) found 4 MAAs (asterina-330, palythinol, palythene, and usijerene) in Gracilariopsis tenuifrons after extraction with ethanol, whereas in this study only palythinol was found in G. longissima, but also shinorine using $20 \% \mathrm{MeOH}$ or $50 \% \mathrm{EtOH}$. The low extraction yield found using ethanol as solvent could explain this result; shinorine was probably present but only in traces and therefore not detectable.

The C:N ratio is used as an indicator of nutrient status. Under limited nutrient resources, especially nitrogen, growth is restricted in photosynthetic organisms, generating an increase in the $\mathrm{C}: \mathrm{N}$ ratio and this means an increase in the production of secondary metabolites (Bryant et al. 2012). Thus, $\mathrm{C}: \mathrm{N}$ is a good indicator of increased production of secondary metabolites related to a decrease in nitrogen-enriched compounds. In relation to the content of antioxidant compounds, Ibrahim and Jaafar (2011) found, in terrestrial plants, that low nitrogen content and therefore high levels of C:N are related to the accumulation of secondary metabolites, that is, an increase in the antioxidant potential of the methanol extracts. These results are consistent with those observed in this study, where species with a high $\mathrm{C}: \mathrm{N}$ ratio presented higher values of antioxidant activity (ABTS and BBM assays).

In conclusion, the 2 species of this study with the highest antioxidant capacity and molecules of biotechnological interest were the red algae Gracilariopsis longissima and Hydropuntia cornea. Halopithys incurva is also a species of interest because of its high levels of phenolic compounds and because it has previously been successfully cultivated (Güenaga 2011). On the other hand, the red alga Gelidium pusillum has high levels of MAAs and polyphenols but there are no available culture techniques. Moreover, numerous studies have pointed out that the first 2 species possess a high capacity to grow by effluent biofiltration (Figueroa et al. 2012), so outdoor culture would be economically viable and environmentally sustainable.

The most suitable solvent for a biotechnological purpose is ethanol $(50 \% \mathrm{EtOH})$, an organic solvent with low toxicity and price. It could be used for the extraction of antioxidant compounds without affecting future application of the extracts. The ABTS method is proposed to determine the antioxidant capacity of algal extracts, as it is an easy, quick,
(330-334 nm) (datos no mostrados). Este intervalo espectral corresponde a la absorción por moléculas fotoprotectoras (AAM) presentes en algunos organismos marinos, como las algas rojas y los líquenes. En U. rotundata no se encontró ninguna absorción en este intervalo espectral y no se detectaron AAM por HPLC. La absorción máxima a $310 \mathrm{~nm}$ en los extractos de L. pygmaeae corresponde al oxo-AAM micosporina-serinol, mientras que los picos de absorción con un máximo de alrededor de 320-334 nm están relacionados con los imino-AAM de algas rojas (palitina, palitinol, shinorina, porphyra -334 y asterina-330).

En nuestro estudio, Gelidium pusillum y G. corneum presentaron palitinol y shinorina como los AAM principales. En general, para todas las especies estudiadas, el contenido de AAM usando EtOH $100 \%$ como solvente fue mucho menor que para otros solventes. Esto puede explicarse debido a la menor polaridad del etanol para interactuar con la parte hidrofóbica de aminoácidos y péptidos. Los AAM pueden diferir entre las especies debido a las condiciones ambientales en las que se encuentren (radiación UV, disponibilidad de nitrógeno, etc.). El contenido de AAM totales en G. pusillum fue aproximadamente 1.7 veces mayor que el de G. corneum debido a que G. pusillum se ubica en la parte superior de la zona intermareal en comparación con $G$. corneum que se ubica en la parte inferior y en zonas submareales y, por lo tanto, la irradiancia diaria integrada en el sitio de crecimiento de G. pusillum es superior a la de G. corneum (Figueroa y Gómez 2001). Los AAM están regulados tanto por la irradiancia como por la calidad lumínica, pero también por la disponibilidad de nitrógeno (Barufi et al. 2011). Torres et al. (2015) encontraron 4 AAM (asterina-330, palitinol, palitene y usijerene) en Gracilariopsis tenuifrons después de realizar una extracción etanólica, mientras que en este estudio se encontró sólo palitinol en G. longissima, pero además shinorina usando $\mathrm{MeOH} 20 \%$ o EtOH $50 \%$. El bajo rendimiento de extracción encontrado usando etanol como solvente podría explicar este resultado. Probablemente shinorina se encontró en trazas fuera del intervalo de detección del HPLC.

La relación $\mathrm{C}: \mathrm{N}$ se utiliza como indicador del estado nutricional. Bajo recursos limitados de nutrientes, especialmente nitrógeno, el crecimiento se ve restringido en los organismos fotosintéticos, lo que genera un aumento en la relación $\mathrm{C}: \mathrm{N}$, el cual significa un aumento en la producción de metabolitos secundarios (Bryant et al. 2012). Por lo tanto, la relación $\mathrm{C}: \mathrm{N}$ es un buen indicador para estimar el aumento en la producción de metabolitos secundarios. En relación con el contenido de compuestos antioxidantes, Ibrahim y Jaafar (2011) encontraron, en plantas terrestres, que el bajo contenido de nitrógeno $\mathrm{y}$, por lo tanto, los altos niveles de C:N están relacionados con la acumulación de metabolitos secundarios involucrados en la capacidad antioxidante. Estos resultados concuerdan con los observados en este estudio, donde especies con una alta relación $\mathrm{C}: \mathrm{N}$ presentaron mayores valores de actividad antioxidante en los ensayos ABTS y BBM. 
and cheap test, and provides a comprehensive view of the entire extract in both lipophilic and hydrophilic media.

In order to gain a better understanding of the mechanisms underlying the antioxidant effects in algae it is necessary to study the structure-activity relationship and the synergy that could occur among molecules, to perform purification and structural analyses of potential antioxidant molecules, and to develop new extraction and purification techniques.

\section{ACKNOWLEDGMENTS}

The financial support provided by the Junta de Andalucía (Spain) to the research project "Photobiology and biotechnology of aquatic organisms" (RNM295) is gratefully acknowledged.

\section{REFERENCES}

Alam MN, Bristi NJ, Rafiquzzaman M. 2013. Review on in vivo and in vitro methods evaluation of antioxidant activity. Saudi Pharm. J. 21: 143-152.

Barufi JB, Korbee N, Oliveira MC, Figueroa FL. 2011. Effects of N supply on the accumulation of photosynthetic pigments and photoprotectors in Gracilaria tenuistipitata (Rhodophyta) cultured under UV radiation. J. Appl. Phycol. 23: 457-466.

Batista-González AE, Charles MB, Mancini-Filho J, Vidal Novoa A. 2009. Las algas marinas como fuentes de fitofármacos antioxidants. Rev. Cuba. Plantas Med. 14: 1-18.

Borowitzka MA. 2013. High-value products from microalgae - their development and commercialisation. J. Appl. Phycol. 25: 743-756.

Brooks JR, Griffin VK, Kattan MW. 1986. A modified method for total carbohydrate analysis of glucose syrups, maltodextrins, and other starch hydrolysis products. Cereal Chem. 63: 465-466.

Bryant JP, Chapin FS, Klein DR, Carbon DR. 2012. Carbon/nutrient balance of boreal plants in relation to vertebrate herbivory. Oikos 40: 357-368.

Chintale Ashwini G, Kadam Vaishali S, Sakhare Ram S, Birajdar Ganesh O, Nalwad Digambar N. 2013. Role of nutraceuticals in various diseases: A comprehensive review. Int. J. Res. Pharm. Chem. 3: 290-299.

Connan S, Delisle F, Deslandes E, Ar Gall E. 2006. Intra-thallus phlorotannin content and antioxidant activity in Phaeophyceae of temperate waters. Bot. Mar. 49: 39-46.

Figueroa FL, Gomez I. 2001. Photosynthetic acclimation to solar UV radiation of marine red algae from the warm-temperate coast of southern Spain: A review. J. Appl. Phycol. 13: $235-248$.

Figueroa FL, Korbee N, Abdala R, Jerez CG, López-de la Torre M, Güenaga L, Larrubia MA, Gómez-Pinchetti JL. 2012. Biofiltration of fishpond effluents and accumulation of $\mathrm{N}$ compounds (phycobiliproteins and mycosporine-like amino acids) versus C-compounds (polysaccharides) in Hydropuntia cornea (Rhodophyta). Mar. Pollut. Bull. 64: 310-318.

Floegel A, Kim DO, Chung SJ, Koo SI, Chun OK. 2011. Comparison of ABTS/DPPH assays to measure antioxidant capacity in popular antioxidant-rich US foods. J. Food Compos. Anal. 24: 1043-1048.

Folin O, Ciocalteau V. 1927. Tyrosine and tryptophane in proteins. J. Biol. Chem. 73: 627-648.
En conclusión, las 2 especies de este estudio con mayor capacidad antioxidante y moléculas con potencial interés biotecnológico fueron las algas rojas Gracilariopsis longissima y Hydropuntia cornea. Halopithys incurva es otra especie interesante debido al alto nivel de compuestos fenólicos que presenta y debido a que anteriormente ya se ha logrado cultivar con éxito (Güenaga 2011). Por otro lado, Gelidium pusillum es también una especie de alga roja con altos niveles de AAM y polifenoles pero actualmente no existen técnicas que permitan su cultivo. Numerosos estudios han demostrado que las 2 primeras especies poseen una alta capacidad de crecimiento en sistemas de biofiltración de efluentes (Figueroa et al. 2012), por lo que su cultivo sería económicamente viable y ambientalmente sostenible.

Se propone como solvente más adecuado para estos fines biotecnológicos el etanol (EtOH 50\%), siendo éste un solvente orgánico con baja toxicidad y con un bajo precio en el mercado actual. Podría ser empleado para la extracción de compuestos antioxidantes al no presentar problemas toxicológicos en las futuras aplicaciones que se deriven de los extractos. El método ABTS se propone para la determinación de la capacidad antioxidante de los extractos algales, ya que es una ensayo fácil, rápido y barato, y además proporciona una visión integradora del extracto tanto en el medio lipofílico como en el medio hidrofílico.

Con el fin de comprender mejor los mecanismos subyacentes a los efectos antioxidantes en las algas, es necesario estudiar la relación estructura-actividad y las sinergias que puedan acontecer entre los componentes, realizar un análisis de purificación y estructural de moléculas potencialmente antioxidantes, así como desarrollar nuevas técnicas de extracción y purificación.

\section{Agradecimientos}

Se agradece el apoyo financiero de la Junta de Andalucía (España) al proyecto de investigación "Fotobiología y biotecnología de organismos acuáticos" (RNM295).

Gómez-Pinchetti JL, Suárez Álvarez S, Güenaga Unzetabarrenechea L, Figueroa FL, García-Reina G. 2011. Posibilidades para el Desarrollo de Sistemas Integrados con Macroalgas en las Islas Canarias y su Entorno, pp. 74-93. ISBN: 978-84-615-4974-0.

Güenaga L. 2011. Influence of solar radiation and ammonium on the accumulation of antioxidant substances in seaweeds grown in a biofiltration system. PhD thesis, Las Palmas G.C. University, Spain, 283 pp.

Gupta S, Abu-Ghannam N. 2011. Recent developments in the application of seaweeds or seaweed extracts as a means for enhancing the safety and quality attributes of foods. Innov. Food Sci. Emerg. Technol. 12: 600-609.

Hernández I, Pérez-Pastor A, Vergara JJ, Martínez-Aragón JF, Fernández-Engo MÁ, Pérez-Lloréns JL. 2006. Studies on the biofiltration capacity of Gracilariopsis longissima: From microscale to macroscale. Aquaculture 252: 43-53. 
Hidalgo ME, Fernández E, Quilhot W, Lissi E. 1994. Antioxidant activity of depsides and depsidones. Phytochemistry 37: 1585-1587.

Holdt SL, Kraan S. 2011. Bioactive compounds in seaweed: Functional food applications and legislation. J. Appl. Phycol. 23(3): 543-597.

Huang D, Boxin OU, Prior RL. 2005. The chemistry behind antioxidant capacity assays. J. Agric. Food Chem. 53: 1841-1856.

Ibrahim MH, Jaafar HZE. 2011. The relationship of nitrogen and C/ $\mathrm{N}$ ratio with secondary metabolites levels and antioxidant activities in three varieties of Malaysian kacip fatimah (Labisia pumila Blume). Molecules 16: 5514-5526.

Kadam SU, Tiwari BK, O’Donnell CP. 2013. Application of novel extraction technologies for bioactives from marine algae. J. Agric. Food Chem. 61: 4667-4675.

Kim DO, Lee KW, Lee HJ, Lee CY. 2002. Vitamin C equivalent antioxidant capacity (VCEAC) of phenolic phytochemicals. J. Agric. Food Chem. 50: 3713-3717.

Korbee-Peinado N, Abdala Díaz RT, Figueroa FL, Helbling EW. 2004. Ammonium and UV radiation stimulate the accumulation of mycosporine-like amino acids in Porphyra columbina (Rhodophyta) from Patagonia, Argentina. J. Phycol. 40: 248-259.

Kuda T, Tsunekawa M, Goto H, Araki Y. 2005. Antioxidant properties of four edible algae harvested in the Noto Peninsula, Japan. J. Food Compos. Anal. 18: 625-633.

López A, Rico M, Rivero A, Suárez de Tangil M. 2011. The effects of solvents on the phenolic contents and antioxidant activity of Stypocaulon scoparium algae extracts. Food Chem. 125: 1104-1109.

Martínez-Aragón JF, Hernández I, Pérez-Lloréns JL, Vázquez R, Vergara JJ. 2002. Biofiltering efficiency in removal of dissolved nutrients by three species of estuarine macroalgae cultivated with sea bass (Dicentrarchus labrax) waste waters. 1. Phosphate. J. Appl. Phycol. 14: 365-374. http://dx.doi.org/10.1023/A:1022134701273

Matanjun P, Mohamed S, Mustapha NM, Muhammad K, Ming CH. 2008. Antioxidant activities and phenolics content of eight species of seaweeds from north Borneo. J. Appl. Phycol. 20: 367-373.

Mishra SK, Suh WI, Farooq W, Moon M, Shrivastav A, Park MS, Yang JW. 2014. Rapid quantification of microalgal lipids in aqueous medium by a simple colorimetric method. Bioresour. Technol. 155: 330-333.

O'Sullivan AM, O'Callaghan YC, O'Grady MN, Queguineur B, Hanniffy D, Troy DJ, Kerry JP, O'Brien NM. 2011. In vitro and cellular antioxidant activities of seaweed extracts prepared from five brown seaweeds harvested in spring from the west coast of Ireland. Food Chem. 126: 1064-1070.

Pereira R, Yarish C. 2010. The role of Porphyra in sustainable culture systems: Physiology and applications. In: Seaweeds and their Role in Globally Changing Environments. Springer, The Netherlands, pp. 339-354.

Plaza M, Santoyo S, Jaime L, García-Blairsy Reina G, Herrero M, Señoráns FJ, Ibáñez E. 2010. Screening for bioactive compounds from algae. J. Pharm. Biomed. Anal. 51: 450-455.

Rabiei R, Phang SM, Lim PE, Salleh A, Sohrabipour J, Ajdari D, Zarshenas GA. 2016. Productivity, biochemical composition and biofiltering performance of agarophytic seaweed, Gelidium elegans (red algae) grown in shrimp hatchery effluents in Malaysia. Iran. J. Fish. Sci. 15:53-74.

Re R, Pellegrini N, Proteggente A, Pannala A, Yang M, Rice-Evans C. 1999. Antioxidant activity applying an improved ABTS radical cation decolorization assay. Free Radic. Biol. Med. 26: 1231-1237.

Robledo D, Navarro-Angulo L, Valdes Lozano D, Freile-Pelegrin Y. 2014. Nutrient removal efficiency of Hydropuntia cornea in an integrated closed recirculation system with pink shrimp Farfantepenaeus brasiliensis. Aquacult. Res. 45: 1648-1658.

Sarikurkcu C, Arisoy K, Tepe B, Cakir A, Abali G, Mete E. 2009. Studies on the antioxidant activity of essential oil and different solvent extracts of Vitex agnus castus L. fruits from Turkey. Food Chem. Toxicol. 47: 2479-2483.

Souza BWS, Cerqueira MA, Martins JT, Quintas MAC, Ferreira ACS, Teixeira JA, Vicente AA. 2011. Antioxidant potential of two red seaweeds from the Brazilian coasts. J. Agric. Food Chem. 59: 5589-5594.

Stengel DB, Connan S, Popper ZA. 2011. Algal chemodiversity and bioactivity: Sources of natural variability and implications for commercial application. Biotechnol. Adv. 29: 483-501. http://dx.doi.org/10.1016/j.biotechadv.2011.05.016

Sun B, Ricardo-da-Silva JM, Spranger I. 1998. Critical factors of vanillin assay for catechins and proanthocyanidins. J. Agric. Food Chem. 46: 4267-4274.

Surveswaran S, Cai YZ, Corke H, Sun M. 2007. Systematic evaluation of natural phenolic antioxidants from 133 Indian medicinal plants. Food Chem. 102: 938-953.

Thomas N, Kim S-K. 2013. Beneficial effects of marine algal compounds in cosmeceuticals. Mar. Drugs 11: 146-164.

Torres PB, Chow F, Santos DYAC. 2015. Growth and photosynthetic pigments of Gracilariopsis tenuifrons (Rhodophyta, Gracilariaceae) under high light in vitro culture. J. Appl. Phycol. 27: 1243-1251.

Viera MP, de Vicose GC, Gómez-Pinchetti JL, Bilbao A, FernandezPalacios H, Izquierdo MS. 2011. Comparative performances of juvenile abalone (Haliotis tuberculata coccinea Reeve) fed enriched vs non-enriched macroalgae: Effect on growth and body composition. Aquaculture 319: 423-429.

Wojdylo A, Oszmiański J, Czemerys R. 2007. Antioxidant activity and phenolic compounds in 32 selected herbs. Food Chem. 105: 940-949.

Yuan YV, Bone DE, Carrington MF. 2005. Antioxidant activity of dulse (Palmaria palmata) extract evaluated in vitro. Food Chem. 91: 485-494.

Yuan YV, Walsh NA. 2006. Antioxidant and antiproliferative activities of extracts from a variety of edible seaweeds. Food Chem. Toxicol. 44: 1144-1150.

Zhao J, Fan X, Wang S, Li S, Shang S, Yang Y, Xu N, Lü Y, Shi J. 2004. Bromophenol derivatives from the red alga Rhodomela confervoides. J. Nat. Prod. 67: 1032-1035.

Zubia M, Freile-Pelegrín Y, Robledo D. 2014 Photosynthesis, pigment composition and antioxidant defences in the red alga Gracilariopsis tenuifrons (Gracilariales, Rhodophyta) under environmental stress. J. Appl. Phycol. 26: 2001-2010.

Received August 2016, accepted November 2016. 